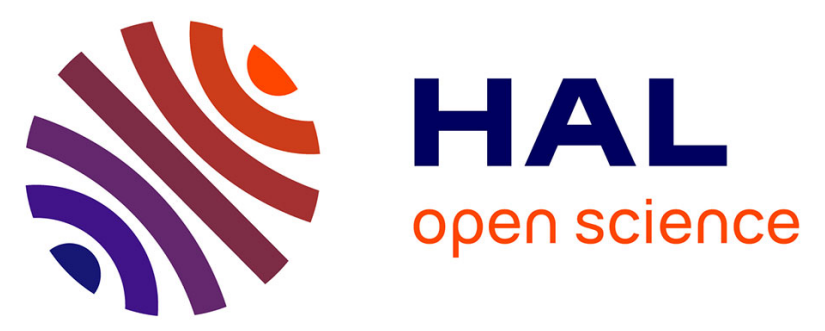

\title{
Mass balance approach to assess the impact of cadmium decrease in mineral phosphate fertilizers on health risk: The case-study of French agricultural soils
}

Géraldine Carne, Stéphane Leconte, Véronique Sirot, Nicolas Breysse, Pierre-Marie Badot, Antonio Bispo, Isabelle Z. Deportes, Camille Dumat, Gilles Rivière, A. A. Crepet

\section{To cite this version:}

Géraldine Carne, Stéphane Leconte, Véronique Sirot, Nicolas Breysse, Pierre-Marie Badot, et al.. Mass balance approach to assess the impact of cadmium decrease in mineral phosphate fertilizers on health risk: The case-study of French agricultural soils. Science of the Total Environment, 2021, 760, 10.1016/j.scitotenv.2020.143374 . anses-03048640

\section{HAL Id: anses-03048640}

\section{https://hal-anses.archives-ouvertes.fr/anses-03048640}

Submitted on 9 Dec 2020

HAL is a multi-disciplinary open access archive for the deposit and dissemination of scientific research documents, whether they are published or not. The documents may come from teaching and research institutions in France or abroad, or from public or private research centers.
L'archive ouverte pluridisciplinaire HAL, est destinée au dépôt et à la diffusion de documents scientifiques de niveau recherche, publiés ou non, émanant des établissements d'enseignement et de recherche français ou étrangers, des laboratoires publics ou privés. 
1

\section{Mass balance approach to assess the impact of cadmium decrease in mineral phosphate fertilizers on health risk: the case-study of French agricultural soils}

G. Carne ${ }^{1}$, S. Leconte ${ }^{1}$, V. Sirot ${ }^{1}$, N. Breysse ${ }^{2}$, P-M Badot ${ }^{3}$, A. Bispo ${ }^{4}$, I.Z Deportes $^{5}$, C. Dumat $^{6}$, G. Rivière ${ }^{1}$, A. Crépet ${ }^{1}$

${ }^{1}$ ANSES, Risk Assessment Department, 14 rue Pierre et Marie Curie, F-94701 Maisons-Alfort Cedex, FRANCE

${ }^{2}$ ANSES, Regulated Products Assessment Department, 14 rue Pierre et Marie Curie, F-94701 Maisons-Alfort

Cedex, FRANCE

${ }^{3}$ UMR 6249, Chrono-Environment, University of Franche-Comté/CNRS, 16, route de Gray, 25000 Besançon, FRANCE

${ }^{4}$ INRAE Orléans US1106 INFOSOL, 2163 avenue de la Pomme de Pin, CS 40001 Ardon, 45075 Orleans cedex 2, FRANCE

${ }^{5}$ ADEME - Service Mobilisation et valorisation des Déchets, 20 avenue du Grésillé, 49004 Angers cedex 01, FRANCE

${ }^{6}$ CERTOP, CNRS, UT2J, UPS, 5 Allée Antonio Machado, 31000 Toulouse, FRANCE

\section{KEYWORDS}

Cadmium, fertilizing materials, soil contamination, food contamination, human exposure, risk assessment

\section{Corresponding Author}

Carne G, French Agency for Food, Environmental and Occupational Health \& Safety (ANSES), Risk Assessment Department, 14 rue Pierre et Marie Curie, F-94701 Maisons-Alfort Cedex, FRANCE. geraldine.carne@anses.fr 
31 Abbreviation, specific definition: fertilisers (UK) = fertilizers (US) include organic, inorganic

32 and organo-mineral fertilizers intended to ensure or improve plant nutrition, and organic, 33 inorganic and organo-mineral soil amendments that improve the physical, chemical and 34 biological properties of soils. 


\section{Abstract}

Cadmium is a ubiquitous and highly toxic contaminant that can cause serious adverse effects. The European Food Safety Authority (EFSA) and the French Agency for Food, Environmental and Occupational Health \& Safety (ANSES) have shown that the risk related to food contamination by cadmium cannot be ruled out in Europe and France. Fertilizing material is one of the main sources of cadmium contamination in the food chain on which regulators can play to reduce cadmium exposure in the population. The aim of this work was to develop a mass-balance approach integrating the various environmental sources of cadmium to estimate the effects of a decrease in cadmium concentrations in crop fertilizers on dietary exposure and on the health risk. This approach led to a predictive model that can be used as a decision-making tool. Representative and protective fertilization scenarios associated with controlled cadmium levels in mineral phosphate fertilizers were simulated and converted into cadmium fluxes. Cadmium inputs from industrial mineral phosphate fertilizers were then compared with cadmium brought by the application of manure, sewage sludge and farm anaerobic digest, at the levels typical of French agricultural practices. Regardless of the fertilizer and scenario used, a flux lower than $2 \mathrm{~g} \mathrm{Cd} \cdot \mathrm{ha}^{-1}$.year ${ }^{-1}$ reduces both the accumulation in soils and the transfer of cadmium in the food chain. It corresponds to a cadmium content of $20 \mathrm{mg} \cdot \mathrm{kg} \mathrm{P}_{2} \mathrm{O}_{5}{ }^{-1}$ or less in mineral phosphate fertilizers. Modelling the transfer of cadmium from the soil to consumed food made it possible to propose cadmium limits in fertilizers applied in France. In a global context of ecological transition to promote human health, this research will help risk managers and public authorities in the regulatory decision-making process for the reduction of environmental cadmium contamination and human exposure. 


\section{Introduction}

Even at low concentrations, cadmium $(\mathrm{Cd})$ is a highly toxic ubiquitous trace element (EFSA, 2009). Environmental Cd levels result partly from its natural occurrence in the earth's crust and mainly from anthropogenic inputs related to industrial, agricultural and transport activities (EFSA, 2009).

In humans, $\mathrm{Cd}$ is widely distributed in the body, where it accumulates over time, with a biological half-life ranging from 10 to 30 years (EFSA, 2009). Cd is mainly found and stored in the liver and kidneys (EFSA, 2009; ATSDR, 2012). Prolonged human oral exposure to Cd induces nephropathy, bone diseases, reproductive disorders and an increased risk of cancer for several organs (lung, prostate and kidneys) (EFSA, 2009). Cd and its compounds are considered as "carcinogenic to humans" (group 1) by the International Agency for Research on Cancer (IARC, 2012).

Excluding smoking, exposure to $\mathrm{Cd}$ in the general population is mainly through diet (EFSA, 2009, 2012). Cd enters the food chain primarily through transfer from soils to crops (EFSA, 2009). Plant roots uptake Cd at a rate that is essentially driven by the chemical species of the element, with soluble $\mathrm{Cd}$ ions being more readily assimilated than insoluble the complexes that Cd can form with inorganic and organic soil constituents. Physico-chemical properties of the soil may also play important roles. For instance, when soil $\mathrm{pH}$ decreases, $\mathrm{Cd}$ bioavailability increases. Soil-plant transfer of $\mathrm{Cd}$ also depends on plant features (species, developmental stage, plant organ, etc.) (Tremel-Schaub and Feix, 2005). Its persistence and the increase in anthropogenic bioavailable forms in the environment and cultivated soils particularly poses a serious human health problem that demands investigation (Shahid et al., 2017)

European (EFSA, 2012) and French (ANSES, 2011a and b) studies have shown that the risk related to Cd dietary exposure cannot be ruled out for a part of the population. In the second French Total Diet Study (TDS) (ANSES, 2011a), the health-based guidance value (HBGV) 
107 defined by EFSA in 2009 was exceeded in $0.6 \%$ of adults and $14.9 \%$ of children over 3 years

108 old. This exceedance of the EFSA HBGV was also observed in younger children in the first 109 French infant TDS, up to $29 \%$ of children aged 13 to 36 months and $36 \%$ of children aged 7 to

11012 months (ANSES, 2016). In both French TDSs (ANSES, 2011a and b, 2016) and at the 111 European level (EFSA 2012), the major contributors to $\mathrm{Cd}$ exposure are cereals and cereal 112 products, vegetables, potatoes and related products.

113 One possible means to reduce exposure is to act on the main food contributors (i.e. such as 114 cereals, vegetables, potatoes), primarily by reducing their levels of contamination at the source 115 or after production using regulatory measures. Limiting exposure requires the implementation 116 or enhancement of $\mathrm{Cd}$ management by controlling environmental releases or processes and/or 117 fixing regulatory thresholds (or reduction of these thresholds if they already exist) to limit the 118 contamination levels of foods identified as the main contributors. However, strengthening 119 regulations on the maximum level of $\mathrm{Cd}$ allowed in food can have a low impact on reducing 120 human exposure due to the ubiquitous Cd contamination according to Jean et al. (2015). It is 121 therefore recommended to take further action on environmental sources and food contamination 122 routes, particularly in regard to fertilizer inputs, identified as the main source of soil and food 123 contamination.

124 In France, mineral phosphate fertilizers have been identified as the main source of $\mathrm{Cd}$ in 125 agricultural soils in arable farming regions (Belon et al., 2012). Phosphate fertilization is 126 adjusted according to the estimated plant phosphorus needs and the availability of phosphorus 127 in the soil. However, there is a sore lack in agronomic field data. Depending on the $\mathrm{Cd}$ 128 concentration and the amounts of fertilizer used for phosphate fertilization, mineral phosphate 129 fertilizers represent a little more than half of the $\mathrm{Cd}$ inputs in French agricultural soils (Belon 130 et al., 2012). Mineral phosphate fertilizers are made from natural phosphate rocks, which can 131 contain $\mathrm{Cd}$, sometimes in quite high concentrations, according to the nature of the rock material 
132 and geographical area from which the rocks are extracted. In sedimentary rocks, for instance,

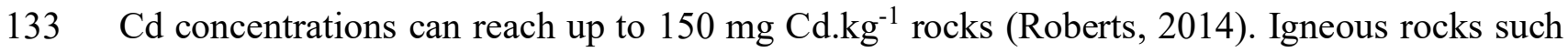

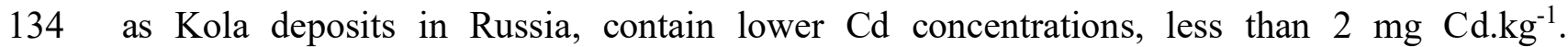

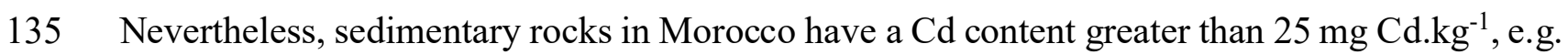
136 in Bou Craa (32-43 mg Cd. $\mathrm{kg}^{-1}$ ) or Youssoufia (4-51 mg Cd. $\mathrm{kg}^{-1}$ ) deposits (Roberts, 2014).

137 In France, there are no natural phosphate deposits, and phosphate rocks are imported. In 138 addition to the use of mineral phosphate fertilizers in France, livestock manure contributes 139 significantly to soil inputs in livestock-farming regions, and represents about $25 \%$ of the total 140 inflow Cd to agricultural soils (Belon et al., 2012).

141 In France, many efforts have already been made to reduce soil $\mathrm{Cd}$ inputs from fertilizers.

142 Regulations have been enacted with safety criteria defined for marketing authorisations (MA)

143 for fertilizers and growing media. According to the instructions that accompany the MA 144 application (guide No 50644\#01, Ministère de l'Agriculture et de la Pêche, 2001), the average 145 annual Cd flux brought to the soil in a 10 year period must not exceed $15 \mathrm{~g} \mathrm{Cd}$. ha ${ }^{-1}$. year ${ }^{-1}$. 146 Moreover, the French standard NF U 42-001-1 currently set a regulatory maximum limit for 147 mineral phosphate fertilizers at $90 \mathrm{mg} \mathrm{Cd} . \mathrm{kg}^{-1}$ per unit mass of phosphoric anhydride $\left(\mathrm{P}_{2} \mathrm{O}_{5}\right)$ 148 equivalent. Although there were defined by Regulation (EC) No 2003/2003, no Cd limit had 149 been previously established for this fertilizer at the European level. In 2016, the European 150 Commission (European Commission, 2016) revised the regulation on EU fertilizing products 151 (Regulation (EU) No 2019/1009 repealing Regulation (EC) No 2003/2003) to propose new 152 limit values for contaminants in EU-labelled fertilizers including $\mathrm{Cd}$, taking into account their 153 adverse effects on humans and the environment. Several Cd levels were discussed for the use 154 of mineral phosphate fertilizers (European Commission, 2016). A Cd concentration of $60 \mathrm{mg}$ 155 Cd.kg $\mathrm{P}_{2} \mathrm{O}_{5}^{-1}$ was adopted, in view of a potential application of this regulation in 2022 156 (Regulation (EU) No 2019/1009). 
157 At the interface between risk assessment and regulatory level, the present study aims to define

158 protective $\mathrm{Cd}$ limit levels in mineral phosphate fertilizers intended to be applied. To do so, a 159 predictive support model was built to evaluate the evolution of $\mathrm{Cd}$ content in French agricultural

160 soils over time, the resulting contamination of crop production and associated dietary exposure

161 and human health risk with respect to $\mathrm{Cd}$ inputs. This predictive model was based on a mass-

162 balance approach (equilibrium calculation between the input and output pathways of $\mathrm{Cd}$ in

163 agricultural soils) combined with a dietary exposure assessment.

164 This original approach linked soil quality, plant quality and dietary exposure to derive and

165 check Cd limits in mineral phosphate fertilizers to protect human and environmental health.

166 The model was first developed for the major source of $\mathrm{Cd}$ input (i.e. mineral phosphate

167 fertilizers) and for the two major field crops contributing to human exposure to Cd, namely

168 wheat and potatoes (ANSES, 2011a, 2011b, 2016). The model was then adapted to other 169 organic fertilizers when scientific data were available.

\section{2. Materials and methods}

\section{$213 \quad 2.1$ Input data for the model}

214 Data used as input parameters for the mass-balance approach applied to French agricultural 215 soils involved soil data, $\mathrm{Cd}$ concentrations in fertilizers, rainwater quantity, agricultural yields 216 and $\mathrm{Cd}$ concentrations due to atmospheric deposition and irrigation water. Table $\mathrm{S} 1$ in

217 supplementary materials describes the data sources and distributions used to model this data, 218 their range of values and the equations used to estimate some model parameters from the data.

219 It also indicates if the variability between plot and year was included or not and how uncertainty 220 was dealt with. 
224 Data came from the French soil quality monitoring network (Réseau de Mesures de la Qualité des Sols, RMQS) which is a systematic grid $(16 \mathrm{~km} \times 16 \mathrm{~km})$ covering all of mainland France with 2240 sites (Arrouays et al., 2002; Arrouays et al., 2020). This network is representative of 227 the French territory, covering a broad spectrum of climatic, soil and land-use conditions 228 (croplands, permanent grasslands, woodlands, orchards and vineyards, natural or weakly anthropogenic lands). Every 15 years at each site, soil samples are taken, measurements are carried out and observations are made. The first campaign occurred from 2000 to 2010 in mainland France. At these sites, the soil organic carbon (SOC) content, particle-size 232 distribution, $\mathrm{pH}$, main total trace elements (As, $\mathrm{Cd}, \mathrm{Co}, \mathrm{Cr}, \mathrm{Cu}, \mathrm{Hg}, \mathrm{Mo}, \mathrm{Ni}, \mathrm{Pb}, \mathrm{Tl}, \mathrm{Zn}$ ) and 233 soil densities were determined for the $0-30$ - and 30-50-cm layers. Samples for laboratory 234 analyses were taken from a bulked sample of 25 core samples from unaligned sampling in a 235 $400 \mathrm{~m}^{2}$ square area. The entire dataset is available on request and the statistical distribution of the results can be downloaded from the INRAE dataverse (Saby et al., 2019).

The concentration of Cd in French soils was mapped across France (Marchant et al., 2010), the mean and median values for $\mathrm{Cd}$ in the top soil $(0-30 \mathrm{~cm})$ were respectively 0.30 and $0.20 \mathrm{mg} \cdot \mathrm{kg}^{-}$

$239{ }^{1}$ dry mass. For modelling, the Cd geochemical background, which represents the Cd present in 240 the soil at the beginning of the simulation, was taken from this dataset restricted to current $\mathrm{Cd}$ 241 levels in French agricultural soils (i.e. cultivated soils and grasslands, other land uses being 242 excluded as non-cultivated with no fertilizer applications). This dataset provided the empirical 243 distribution of $\mathrm{Cd}$ levels associated with the geochemical background in French agricultural 244 soils. All other parameters needed for modelling (i.e. apparent soil density, concentrations of 245 organic matter, clay, carbon, and soil $\mathrm{pH}$ ) came from the same RMQS dataset including 2059 246 agricultural soils. 
247 Our models took the diversity of soil composition found in France into account by randomly 248 sampling one RMQS site in the dataset, represented by a vector, including its Cd geochemical 249 background, concentrations of organic matter, clay, carbon, and soil $\mathrm{pH}$.

250 Cd inputs due to atmospheric deposition

251 The Cd concentration due to atmospheric deposition on French agricultural soils came from the 252 empirical distribution proposed in Belon et al. (2012).

\section{Cd inputs from irrigation water}

254 Cd concentrations from irrigation water were calculated by combining the irrigation quantity 255 of each crop with the Cd concentration in the irrigation water. The quantity of irrigation water 256 for each crop was modelled by applying a triangular distribution to the French ARVALIS 257 research institute database (ARVALIS, 2011 and 2013). A truncated normal distribution was 258 applied to the data from the geochemical atlas of Europe linked to the FOREGS database 259 (FOREGS, 2005 and 2006) to model Cd concentrations in irrigation water.

\section{Rainwater quantity}

261 Rainwater quantity was integrated in the model by using the empirical distribution from data of 262 the Agri4cast resources portal (JRC): Agri4Cast Resources Portal. Gridded Agro263 Meteorological Data in Available at 264 https://agri4cast.jrc.ec.europa.eu/DataPortal/Index.aspx?o $=$ for the 2005-2015 period of 265 precipitations in France.

266 Agricultural yields

267 Yields specific to each crop were simulated from a triangular distribution applied to data from 268 the French ARVALIS research institute (ARVALIS, 2013). 
272 Concentration in foods came from the second French TDS, in which Cd was analysed in 1319

273 food composite samples representative of the whole diet of the population and prepared "as 274 consumed" (Millour et al., 2011). Left-censored data were managed by calculating a lower 275 bound (LB) and an upper bound (UB) hypothesis by adapting WHO recommendations (WHO, 276 2013). In the LB approach, non-detected results and detected-but-non-quantified results were 277 respectively replaced by zeros and by the limit of detection (LOD). In the UB approach, non278 detected results were replaced by the LOD and detected-but-non-quantified results were 279 replaced by the limit of quantification (LOQ). Because the quantification rate was high, results 280 were similar under both hypotheses, and only the UB approach is presented in the present work 281 as recommended by the WHO (2013).

\section{Food consumption}

283 Consumption data came from the French national and individual food consumption survey 284 (INCA2) (Dubuisson et al., 2010; Lioret et al 2010). In this survey, food and beverage 285 consumption was assessed through a 7 consecutive day record for a random sample of the 286 French population drawn using a multistage cluster sampling technique. Individual body 287 weights were also measured. For this study, data from 1918 adults aged 18-79 years and 1444 288 children aged 3-17 years were used.

$\underline{2.2 \text { Fertilization scenarios and Cd input via mineral phosphate fertilizers }}$

291 Wheat was studied in monoculture or in rotation with potatoes over three years 292 (potatoes/wheat/wheat) following common agricultural practices of French fertilizations plans 293 as recommended by the Comité Français d'Etude et de Développement de la Fertilisation. Raisonnée (COMIFER, 2009) and ARVALIS (ARVALIS, 2018). 
296 Representative mineral phosphate fertilizer plans for French agricultural soils were modelled. 297 They were linked to protective scenarios of $\mathrm{Cd}$ input selected for the risk assessment. The 298 fertilization plans most likely to add Cd to agricultural soils were selected. They were associated 299 with low phosphorus concentrations in soils (i.e. one-third of the soils in France (Delmas et al., 300 2015, Saby et al., 2016) according to the phosphorus requirements of plants. Phosphate 301 fertilizations plans based on annual applications and applications every 3 years of phosphate 302 mineral fertilizer intake were included in the predictive model. Realistic but representative and 303 reduced-Cd phosphate fertilization plans were simulated for an annual phosphate application 304 of 80 and $100 \mathrm{~kg} \mathrm{P}{ }_{2} \mathrm{O}_{5} \cdot \mathrm{ha}^{-1}$ for wheat and for the potatoes/wheat/wheat rotation. Phosphate 305 fertilization plans with two years without fertilization were tested applying 100 and $180 \mathrm{~kg}$ $306 \mathrm{P}_{2} \mathrm{O}_{5} \cdot \mathrm{ha}^{-1}$ for wheat and for the potatoes/wheat/wheat rotation. Although realistic, these 307 scenarios can be considered as worst case scenarios, because in France the mean phosphorus 308 application rates on wheat and potato crops are $53 \mathrm{~kg} \cdot \mathrm{ha}^{-1} \mathrm{P}_{2} \mathrm{O}_{5}$ and $84 \mathrm{~kg} \cdot \mathrm{ha}^{-1} \mathrm{P}_{2} \mathrm{O}_{5}$ respectively 309 (Sterckeman et al., 2018a).

\section{Cd concentrations tested in mineral phosphate fertilizers}

311 Cd concentrations in mineral phosphate fertilizers proposed in the French and European 312 regulations were studied. The level of $90 \mathrm{mg} \mathrm{Cd} . \mathrm{kg} \mathrm{P}_{2} \mathrm{O}_{5}{ }^{-1}$ set by the French standard NF U $42-$ 313 001-1 was used here and considered as the 'reference scenario'. The reduced Cd concentrations 314 already discussed at the European level (European Commission, 2016) for a harmonised 315 European regulation on mineral phosphate fertilizers with 60, 40 and $20 \mathrm{mg} \mathrm{Cd.kg} \mathrm{P}_{2} \mathrm{O}_{5}{ }^{-1}$ were 316 selected here, including the level adopted in Regulation (EU) No 2019/1009. For organo317 mineral fertilizers, the European Commission also proposed a plan with application EC-labelled 318 fertilizer with $60 \mathrm{mg} \mathrm{Cd.kg} \mathrm{P}_{2} \mathrm{O}_{5}{ }^{-1}$, then 3 years after application a reduction of this threshold 
to $40 \mathrm{mg} \mathrm{Cd} . \mathrm{kg} \mathrm{P}_{2} \mathrm{O}_{5}{ }^{-1}$ and finally after 12 years to $20 \mathrm{mg} \mathrm{Cd} \cdot \mathrm{kg} \mathrm{P}_{2} \mathrm{O}_{5}{ }^{-1}$ (European commission,

320 2016). This scenario was also studied in our work.

321

322

\section{Cd fluxes due to mineral phosphate fertilizers}

The phosphate application doses were matched with various $\mathrm{Cd}$ levels in phosphate fertilizers to determine annual $\mathrm{Cd}$ fluxes in agricultural soils via phosphate fertilizers, expressed in g.ha ${ }^{-}$ ${ }^{1}$.year ${ }^{-1}$. Table 1 gives the scenarios and their associated names according to the phosphate fertilizer plans $(\mathrm{Ph})$, the phosphate input dose related to the plant requirements for a wheat monoculture crop (b) or a potatoes/wheat/wheat rotation (bp), and the modelled $\mathrm{Cd}$ concentration, e.g. $\mathrm{Ph} / 80 \mathrm{~b} / 90$ indicates a phosphate fertilizer plan with an application of $80 \mathrm{~kg}$ $\mathrm{P}_{2} \mathrm{O}_{5} \cdot \mathrm{ha}^{-1}$ for wheat monoculture and a Cd input of $90 \mathrm{mg} \mathrm{Cd} \cdot \mathrm{kg} \mathrm{P}_{2} \mathrm{O}_{5}{ }^{-1}$. Accordingly, our reference scenarios are $\mathrm{Ph} / 80 \mathrm{~b} / 90, \mathrm{Ph} / 100 \mathrm{~b} / 90, \mathrm{Ph} / 100 \mathrm{bp} / 90, \mathrm{Ph} / 180 \mathrm{bp} / 90$. The reduced-Cd scenarios model 60, 40, $20 \mathrm{mg} \mathrm{Cd.kg} \mathrm{P}_{2} \mathrm{O}_{5}{ }^{-1}$ at fixed and degressive (e.g. reduction 3 years after first application, then again 12 years thereafter) levels. Coupling the application dose with the Cd content to be tested according to the fertilization plan (wheat monoculture or rotation) resulted in 20 fertilization plan scenarios to be tested in the model. These scenarios gave $\mathrm{Cd}$ fluxes varying from 0.67 to $9 \mathrm{~g} \mathrm{Cd} \cdot \mathrm{ha}^{-1} \cdot \mathrm{year}^{-1}$ (Table 1).

\section{$\underline{2.3 \text { General model }}$}

The model developed to estimate the effect of reduced $\mathrm{Cd}$ in fertilizers on consumer exposure and risk over time comprised two steps (Figure 2). The first step modelled the transfer of Cd from environmental sources (irrigation water, soil, atmospheric deposition and fertilizers) to plants. It was based on a probabilistic parameterisation of a mass-balance approach and made it possible to study the effect of reducing $\mathrm{Cd}$ in fertilizers on the $\mathrm{Cd}$ concentration in plants, according to the expected Cd concentration in the fertilizer. The second step assessed the effect of reduced $\mathrm{Cd}$ on consumer exposure and risk. It studied the potential percentage of decrease in $\mathrm{Cd}$ levels in food according to the various reduced-Cd (protective) scenarios. 
Mass-balance approach to estimate $C d$ in soil in year $i$

$\mathrm{Cd}$ concentrations in soil were estimated using a mass-balance approach linked to different sources of $\mathrm{Cd}$ in agricultural soil and its elimination. This approach was based on the method proposed by Six and Smolders (2014), and implemented for specific French soils as described in Sterckeman et al. $(2018 \mathrm{a}, \mathrm{b})$. The soil Cd concentration in year i, $[\mathrm{Cd}]_{\text {soil,i }}\left(\mathrm{mg}^{\mathrm{k}} \mathrm{kg}^{-1}\right)$, was calculated by adding the soil $\mathrm{Cd}$ concentration in soil at year i-1 $[\mathrm{Cd}]_{\text {soil,i-1 }}\left(\mathrm{mg}_{\mathrm{kg}} \mathrm{kg}^{-1}\right)$ to $\mathrm{Cd}$ inflows (mineral phosphate fertilizer, atmospheric deposition and irrigation water) minus $\mathrm{Cd}$ outflows (elimination by leaching and plant transfer) divided by the mass of the $0-30 \mathrm{~cm}$ layer per hectare $\left(\mathrm{W}_{\text {soil }}\right)\left(\mathrm{kg} \cdot \mathrm{m}^{-3}\right)($ Eq. (1)).

$$
[C d]_{s o i l, i}=[C d]_{s o i l, i-1}+\frac{(\text { cadmium inflows-cadmium outflows })}{W_{\text {soil }}}
$$

\section{Cd transfer in plant and leaching}

360 Modelling of cadmium outflows from agricultural soil to plants (wheat grain and potato) was based on the integration of transfer equations from Franz et al. (2008) and Ran et al. (2016),

362 given in Table S1. These equations were selected on the basis of the following criteria: (i) a 363 non-industrial origin of soil Cd contamination, (ii) a pertinent correlation coefficient and (iii) 364 the possibility to include the parameters of the equation using available French soil input data 365 presented in section 2.1. The equations specifically took into account crop uptake factors linked to soil physico-chemical characteristics with distributions of soil organic matter concentrations,

367 clay and carbon and also soil $\mathrm{pH}$. 
The annual amount of $\mathrm{Cd}$ leaching was calculated by determining the $\mathrm{Cd}$ concentration in the

369 soil solution using on the formula elaborated by De Vries (2011 and 2013) (Table S1). We also 370 determined the volume of soil solution removed from the soil layer considered $(30 \mathrm{~cm})$ each year. This volume was estimated as a percentage of the volume of water the plot receives each year, assuming that $30 \%$ of this water is irrigation water and the rest $(70 \%)$ rainwater.

\section{Simulations over 99 years integrating variability and uncertainty}

374 Cd concentrations in soil, wheat grains, potatoes and leachate were simulated over 99 years 375 using Monte Carlo simulations. For a given fertilization plan, 10,000 plots were simulated to account for the diversity of plots in France. To simulate one plot, a vector containing the $\mathrm{Cd}$ concentration related to the geochemical background, concentrations of organic matter, clay and carbon, and soil $\mathrm{pH}$ was selected from the RMQS dataset, which allowed us to integrate correlations observed between these parameters in the French plots. For parameters such as 380 rainwater quantity, agricultural yields or irrigation water quantity, which varied from plot to 381 plot and from year to year, variability was accounted for by randomly selecting a value per plot and per year in their associated distributions. Increases or decreases in Cd concentrations were then calculated on the modelling period for the 10,000 plots. A sensitivity analysis on the 384 number of simulated plots was performed and showed that simulating 10,000 plots was 385 sufficient to obtain stable results. The mass balance for each simulation was also verified. The 386 algorithm was programmed using $\mathrm{R}$ software (version 3.4.0, 21-04-2017). The means and 387 percentiles of $\mathrm{Cd}$ concentrations in soil, plants (wheat grains and potato) and leachate over time 388 for all plots are given in tables and graphs. Differences in concentrations in the different 389 matrices (soil, plant or leachate) between years were also analysed in regard to the Cd content, 390 soil $\mathrm{pH}$ and whether the $\mathrm{Cd}$ concentration between the first year of application and the 99 year increased or decreased. 
consumed

395 French exposure to Cd was first calculated by combining consumed quantities from the INCA

2 study with the Cd concentration in food from the TDS considering all food items contaminated by $\mathrm{Cd}$. The resulting exposure was considered as the 'starting scenario'.

398 Then, variations in Cd concentrations over time expressed as a mean percentage decrease or 399 increase in plants based on the fertilization scenarios were applied to the mean $\mathrm{Cd}$ 400 contamination of soft and durum wheat- and potato-based foods of the TDS, using the method 401 described in Jean et al. (2015). Corresponding consumer exposure levels for each fertilization 402 scenario were assessed. Reduced-Cd scenarios were compared with both the reference scenario 403 (French regulatory $\mathrm{Cd}$ cadmium concentration in mineral phosphate fertilizer) and the starting 404 scenario.

405 Mean, standard deviation (SD) and $95^{\text {th }}$ percentiles of exposure (P95) were calculated for adult 406 and child populations, for each scenario and each period (10, 20, 60 and 99 years). In addition, 407 the health risk linked with each exposure was assessed by calculating the percentage of 408 individuals exceeding the $\mathrm{HBGV}$, with its $95 \%$ confidence interval ( $\mathrm{CI}_{95} \%$ ). In the present work, 409 a HBGV for Cd by ingestion of $0.35 \mu \mathrm{g} \cdot \mathrm{kg} \mathrm{bw}^{-1} \cdot \mathrm{d}^{-1}$ was used on the basis of a physiologically 410 based toxicokinetic model modelling lifelong exposure to $\mathrm{Cd}$ and considering the effects on 411 bones as critical effects (ANSES, 2019). 


\section{Results}

\section{$\underline{3.1 \text { Environmental contamination and consumer exposure }}$}

\section{$\underline{\text { 3.1.1 Mass-balance modelling results }}$}

Table 2 presents the mean Cd variation for the various scenarios modelled.

422 Probabilistic parameterisation of the mass-balance approach allowed a presentation of a 423 distribution of percentage variation in $\mathrm{Cd}$ concentration in the matrix over time. We used 424 boxplots to explore and visualise two fertilizations plans of interest. Figure 3 presents the plan 425 with the greatest $\mathrm{Cd}$ accumulation over time in soil, plants and leachates associated with wheat monoculture receiving an annual application of $80 \mathrm{~kg} \mathrm{P}_{2} \mathrm{O}_{5} \cdot \mathrm{ha}^{-1} \cdot \mathrm{year}^{-1}(\mathrm{Ph} / 80 \mathrm{~b} / 90, \mathrm{Ph} / 80 \mathrm{~b} / 60$, $\mathrm{Ph} / 80 \mathrm{~b} / 40$ and $\mathrm{Ph} / 80 \mathrm{~b} / 20$ ). As of 10 years and thereafter, Cd content increases significantly in soils and plants over time (about 10\% variation) in line with increasing Cd concentrations in

429 fertilizers, from 40 to $90 \mathrm{mg} \cdot \mathrm{kg}^{-1} \mathrm{P}_{2} \mathrm{O}_{5}$. The mean rate of increase in Cd concentration reaches 430 up to $64 \%$ in plants and $72 \%$ in leachates over the 99 -year period for the $\mathrm{Ph} / 80 \mathrm{~b} / 90$ reference 431 scenario, representing the current French regulatory threshold of $90 \mathrm{mg}$ Cd.kg $\mathrm{P}_{2} \mathrm{O}_{5}{ }^{-1}$. Cd 432 content in soils and plants are contained only at a level of $20 \mathrm{mg} \mathrm{Cd} \cdot \mathrm{kg}^{-1} \mathrm{P}_{2} \mathrm{O}_{5}$ in this fertilization 433 plan.

434 The potato/wheat/wheat rotation fertilization plan of $180 \mathrm{~kg} \mathrm{P}_{2} \mathrm{O}_{5} \cdot \mathrm{ha}^{-1}$.year ${ }^{-1}$ with a two-year 435 hiatus in fertilisation $(\mathrm{Ph} / 180 \mathrm{bp} / 90, \mathrm{Ph} / 180 \mathrm{bp} / 60, \mathrm{Ph} / 180 \mathrm{bp} / 40$ and $\mathrm{Ph} / 180 \mathrm{bp} / 20)$ showed the 436 greatest decrease in $\mathrm{Cd}$ accumulation in the soil and reduction in its transfer to plants and 437 leachate among all simulations over time (Figure 4). In contrast to maintaining the current 438 French regulatory threshold of $90 \mathrm{mg} \mathrm{Cd} \cdot \mathrm{kg} \mathrm{P}_{2} \mathrm{O}_{5}{ }^{-1}$ in the $\mathrm{Ph} / 180 \mathrm{bp} / 90$ reference scenario, the 439 decrease in $\mathrm{Cd}$ input by reducing $\mathrm{Cd}$ concentrations as much as possible in mineral phosphate 440 fertilizers tends to limit its accumulation in French agricultural soils and its transfer to plants 441 and leachate over time. Based on the distributions and the mean Cd concentration (Figure 4), a 
442 significant reduction in the transfer of $\mathrm{Cd}$ to wheat (grain) and potato was observed as of 10 443 years for phosphate fertilizers with contents equal or less than $40 \mathrm{mg} \mathrm{Cd.kg} \mathrm{P}_{2} \mathrm{O}_{5}{ }^{-1}$. This 444 decrease was enhanced for the even lower fertilizer Cd content of $20 \mathrm{mg} \mathrm{Cd} \cdot \mathrm{kg} \mathrm{P}_{2} \mathrm{O}_{5}{ }^{-1}$. In this 445 latter plan, a decrease greater than $25 \%$ of $\mathrm{Cd}$ accumulation in French agricultural soils and its 446 transfer is reached over the 99-year period with the distribution of percentage variation in $\mathrm{Cd}$ 447 concentration in matrices at the $25^{\text {th }}$ percentile using a set of French soil combinations. 448 Compared with the first year of application, a greatest mean percentage of reduction in $\mathrm{Cd}$ 449 concentration in matrices $(21 \%)$ was observed at the lowest simulated Cd concentration (20 450 mg.kg ${ }^{-1} \mathrm{P}_{2} \mathrm{O}_{5}$ ) over the 99-year period (Table 2). The reduction in the Cd concentration in plants 451 depending on the action at the source of $\mathrm{Cd}$ was more pronounced for wheat grain than for 452 potato tuber.

453 The trends observed in Table 2 and Figures 3 and 4 show that, at the two highest $\mathrm{Cd}$ 454 concentrations (60 and $90 \mathrm{mg} \mathrm{Cd} \cdot \mathrm{kg} \mathrm{P}_{2} \mathrm{O}_{5}{ }^{-1}$ ), $\mathrm{Cd}$ accumulates in the soil and a significant 455 proportion is transferred to plants and leaching water over time, regardless of the fertilization 456 plan in wheat monoculture or potato/wheat/wheat rotation, with or without a two-year hiatus in 457 fertilization. A contrario, with a decrease in Cd concentration to $20 \mathrm{mg} \mathrm{Cd} \cdot \mathrm{kg}_{2} \mathrm{O}_{5}{ }^{-1}$ in the 458 commercial mineral phosphate fertilizer, $\mathrm{Cd}$ accumulation in soils and in its transfer to plants 459 and leachate stabilises and even decreases: see scenarios $\mathrm{Ph} / 80 \mathrm{~b} / 20, \mathrm{Ph} / 100 \mathrm{~b} / 20, \mathrm{Ph} / 100 \mathrm{bp} / 20$, $460 \mathrm{Ph} / 180 \mathrm{bp} / 20$, with an average $\mathrm{Cd}$ transfer decrease of up to $-18 \%$ after 99 years (Table 2 ). Cd 461 is preferentially transferred into leaching water than into the soil and plant matrices. Lower Cd 462 concentrations decreased this transfer to the ground water and surface water.

463 When realistic fertilizer application scenarios were tested using the degressive Cd model $464(\mathrm{Ph} / 80 \mathrm{~b} / 60-40-20, \mathrm{Ph} / 100 \mathrm{~b} / 60-40-20, \mathrm{Ph} / 100 \mathrm{bp} / 60-40-20, \mathrm{Ph} / 180 \mathrm{bp} / 60-40-20), \mathrm{Cd}$ transfer to 465 the plant and to leaching water is reduced, and the soils gradually become less contaminated. 466 For example, Figure 5 shows this trend for $\mathrm{Ph} / 180 \mathrm{bp} / 60-40-20$, representative of agricultural 
467

468

469

470

471

472

473

474

475

476

477

478

479

480

481

482

483

484

485

486

487

488

489

490

491

conditions in France. In this scenario, $\mathrm{Cd}$ is reduced by, on average, $16 \%$ in soils and wheat grain, $13 \%$ in potatoes and of $20 \%$ in leachate over 99 years, reaching a Cd concentration in mineral phosphate fertilizers of $20 \mathrm{mg} \mathrm{Cd} \cdot \mathrm{kg} \mathrm{P}_{2} \mathrm{O}_{5}{ }^{-1}$ in 15 years.

\section{$\underline{\text { 3.1.2 Effects of soil characteristics on Cd transfer }}$}

Figure 6 illustrates, as an example in a more exposed situation, the variation in Cd concentration depending on soil $\mathrm{pH}$ for a wheat monoculture fertilization plan with an annual application of $80 \mathrm{~kg} \mathrm{P}_{2} \mathrm{O}_{5} \cdot \mathrm{ha}^{-1}$.year ${ }^{-1}$ between the first year of application and after 99 years.

There is a risk of $\mathrm{Cd}$ accumulation in acid, neutral or alkaline soils as well as of $\mathrm{Cd}$ transfer to plants for mineral phosphate fertilizers with a $\mathrm{Cd}$ content greater than $40 \mathrm{mg} \mathrm{Cd} \cdot \mathrm{kg}_{2} \mathrm{O}_{5}{ }^{-1}$ for the following soils:

- soils with $\mathrm{pH}<6.5$, representing 50\% of the agricultural soils in France (Saby et al., $2019)$;

- soils with $\mathrm{pH}>7.5$, representing $30 \%$ of the agricultural soils in France (Saby et al., 2019).

\subsubsection{Health risk assessment for the consumer}

Figure 7 shows the percentages of adults and children exceeding the Cd HBGV intake of 0.35 $\mu \mathrm{g} . \mathrm{kg} \mathrm{bw}^{-1} \cdot \mathrm{d}^{-1}$ for different scenarios (ANSES, 2019) under the UB hypothesis. Compared with the starting scenario corresponding to current exposure levels (ANSES, 2011a), the reducedCd scenarios (20 mg Cd.kg $\left.\mathrm{P}_{2} \mathrm{O}_{5}^{-1}\right)$, on a constant or degressive basis $(\mathrm{Ph} / 80 \mathrm{~b} / 20, \mathrm{Ph} / 180 \mathrm{bp} / 20$, $\mathrm{Ph} / 100 \mathrm{~b} / 60-40-20$ and $\mathrm{Ph} / 180 \mathrm{bp} / 60-40-20$ scenarios), lead to a lower exceedance of the HBGV. Nevertheless, the risk remains significant in adults and children, for whom the percentage exceeded $12 \%$ even after 99 years. Only the $\mathrm{Ph} / 180 \mathrm{bp} / 20$ and $\mathrm{Ph} / 180 \mathrm{bp} / 60-40-20$ scenarios show a significant decrease in this percentage in children after 99 years.

In the reference scenarios corresponding to the current French regulatory threshold of $90 \mathrm{mg}$ Cd.kg $\mathrm{P}_{2} \mathrm{O}_{5}{ }^{-1}$ in mineral phosphate fertilizers $(\mathrm{Ph} / 80 \mathrm{~b} / 90$ and $\mathrm{Ph} / 100 \mathrm{bp} / 90)$, the percentages of 
exceedance are significantly higher than in the starting scenario $(\mathrm{p}<0.05)$. For adults, this

493 increase is significant after 60 or 99 years of projection. In these situations, the percentage of

494 children in which HBGV is exceeded doubles after the projected 99 years, while for one-third

495 or more, it is not be possible to rule out a risk.

496 In fertilization plans associated with a fertilizer Cd content of $20 \mathrm{mg} \mathrm{Cd} \mathrm{kg} \mathrm{P}_{2} \mathrm{O}_{5}{ }^{-1}$ (constant or 497 degressive $\mathrm{Cd}$ content scenarios), an exceedance of the HBGV in adults and children is 498 undeniably observed, but with a significant reduction after 99 years.

\section{$\underline{3.2 \text { Comparison of } \mathrm{Cd} \text { fluxes via fertilizing materials }}$}

501 Cd fluxes via mineral phosphate fertilizers were compared with those via sewage sludge, cattle 502 manure and anaerobic digestates currently used in France for soil improvement. The inclusion 503 of these fertilizing materials is based on the availability of data giving results for common 504 French agronomic practices for wheat monoculture fertilization plans. Compared with $\mathrm{Cd}$ 505 fluxes derived for mineral phosphate fertilizers (Table 1), the fluxes for these organic fertilizers

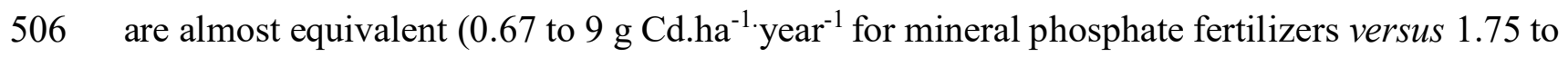
$5077.50 \mathrm{~g} \mathrm{Cd} \mathrm{ha}^{-1} \mathrm{year}^{-1}$ for organic fertilizers). Cd inputs to soils from applications of organic 508 fertilizers are mainly attributed to high application quantities, because the Cd concentrations in 509 these organic materials are generally low or intermediate compared with inorganic fertilizers as 510 shown in Table 3.

511 Figure 8 shows the results of $\mathrm{Cd}$ accumulation in French agricultural soils and its transfer to 512 plants and leachates over the 99-year period obtained using fluxes from different fertilizing 513 materials according to wheat monoculture agricultural practises in France. Cd accumulation in 514 the soil and its transfer to wheat grains decreases following fertilization plans with an annual

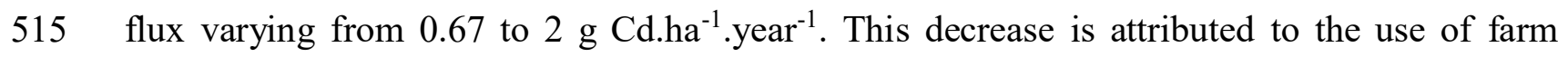
anaerobic digestates with a mean $\mathrm{Cd}$ concentration of $0.70 \mathrm{mg} \cdot \mathrm{kg}^{-1}$ of dry matter (DM) and 
517 mineral phosphate fertilisers with a Cd content of $20 \mathrm{mg} \mathrm{Cd} \cdot \mathrm{kg} \mathrm{P}_{2} \mathrm{O}_{5}{ }^{-1}$. The condition without

518 added $\mathrm{Cd}$ from agronomic inputs ( $\mathrm{Cd}$ inputs only come from atmospheric deposition and

519 irrigation water, in addition to the geochemical background) was also tested.

520 Results (not shown) show that the levels in the three media considered are below and close to 521 the lowest $\mathrm{Cd}$ dose in a mineral phosphate fertilizer (i.e. $\mathrm{Ph} / 80 \mathrm{~b} / 20$; Figure 8).

\section{Discussion}

524 Our results indicate that limiting the inputs of persistent and bioavailable $\mathrm{Cd}$ in the environment 525 — particularly in agricultural soils used to produce food - is a prerequisite to reducing contamination in the food chain and thus human exposure to $\mathrm{Cd}$ and subsequent health risk.

4.1 Mass-balance and consumer exposure combining approaches to assess the $\mathrm{Cd}$ risk via the application of fertilizers to cultivated soils

As required by the European Regulation project (European Commission, 2016), our methodology explored the link between the evolution of $\mathrm{Cd}$ contamination in soils and plants

532 and the ultimate consumer exposure from food intake in a health risk assessment context. Thus, 533 our assessment addresses the effects of actions at the source, through the use of representative environmentally and protective fertilization plans. The model also comprehensively addressed the accumulation of $\mathrm{Cd}$ over time in various compartments (soil, plants and leachates) and the 536 possible health effects for consumers.

537 Six and Smolders (2014) updated the mass-balance approach initiated in 2002 by the Scientific 538 Committee on Toxicity, Ecotoxicity and the Environment (CSTEE) by integrating the inventory 539 of Cd inputs to agricultural soils in the EU $27+$ Norway $($ EU27 + 1) with recent data on 540 atmospheric deposition, phosphate fertilizers, sludge, lime and manure applications for soils 
used for arable production of cereal and potato crops. However, they used mean estimates of

542 input variables. Thus, although their assumptions were realistic and encompassed the majority

543 of current situations, their assessment can be improved by taking into account the variability of

544 input data and local situations in particular the ones corresponding to Cd overexposure through

545 particular soil/ plant/input combinations, as explored here in this study. Römkens et al. (2017)

546 and Sterckeman et al. (2018a, b) implemented the mass-balance approach with the integration

547 of data focusing on a more precise geographical scale respectively at the European regional

548 level and in France by integrating soil variability. However, their approach focused only on Cd

549 transfer in soil and plants and did not study their impact on food products. Furthermore,

550 previous studies have already expressed the need for a joint assessment of the trends of

551 accumulation of $\mathrm{Cd}$ in soil and the general dietary exposure of the population to $\mathrm{Cd}$ (Rietra et

552 al., 2017; KEMI, 2011).

553 Based on probabilistic parameterisation in a mass-balance approach, our model made it possible

554 to simulate $\mathrm{Cd}$ transfer from agricultural soils to food consumed by the French population and

555 account for variability in French soils, local specificities and agricultural practices. This

556 approach has the advantage of being based on reliable input parameters drawn from currently

557 available data. If country-specific data on soil typology and the contamination of foods

558 consumed are available, our approach can be extended to other European and non-European

559 countries. This approach can also be developed to study other contaminants or metals, such as

560 lead $(\mathrm{Pb})$, and their evolution in the case of polluted soils or population overexposure.

561 Our model, based on realistic scenarios of $\mathrm{Cd}$ inputs to the soil, provided estimations of $\mathrm{Cd}$

562 concentrations in plants (wheat and potatoes) and leachates consistent with those observed in

563 Europe.

564 For example, simulated plant Cd concentrations at the start of the simulations (median of 0.07

$565 \mathrm{mg} \mathrm{Cd} \cdot \mathrm{kg}^{-1}$ in wheat grains and $0.04 \mathrm{mg} \mathrm{Cd} \cdot \mathrm{kg}^{-1}$ in potatoes) were of the same order of 
magnitude as those measured by the French monitoring programs during the $2010-2015$ period

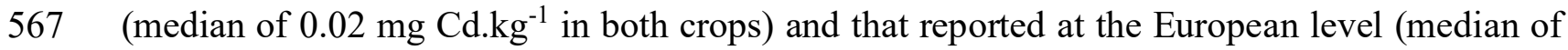
$0.02 \mathrm{mg} \mathrm{Cd} . \mathrm{kg}^{-1}$ for the two crops (EFSA, 2009). Also, Cd concentrations derived for leachates at the start of the simulations were quite similar to the data reported in Six and Smolders (2014).

570 Our model provided a mean maximum leached Cd content for each simulation of $2.4 \mathrm{~g} \mathrm{Cd}$.ha ${ }^{-}$

$571{ }^{1}$.year-1 ${ }^{-1}$ whereas Six and Smolders (2014) reported a mean leaching rate in Europe of $2.56 \mathrm{~g}$ $572 \mathrm{Cd} \cdot \mathrm{ha}^{-1}$.year ${ }^{-1}$. Our models were thus appropriate for conducting a quantitative health risk assessment.

574 Moreover, our model gave mean estimates of the progressive decrease in $\mathrm{Cd}$ accumulation in soils over time at the lowest $\mathrm{Cd}$ concentration $\left(20 \mathrm{mg} \mathrm{Cd} \cdot \mathrm{kg} \mathrm{P}_{2} \mathrm{O}_{5}{ }^{-1}\right)$, with $-17 \%$ over a 99 -year 576 period. These estimates are close to those obtained by Smolders and Six (2014): $-20 \%$ to $-14 \%$ 577 with a medium fertilizer Cd concentration between 0 and $40 \mathrm{mg} \mathrm{Cd} . \mathrm{kg} \mathrm{P}_{2} \mathrm{O}_{5}{ }^{-1}$.

578 Here, our model included several uncertainties that can be reduced by including additional supplementary data that remain to be acquired. For example, we only considered wheat and potatoes, because they were identified as major contributors to consumer $\mathrm{Cd}$ exposure through 581 food products (EFSA, 2012, ANSES, 2011a,b, 2016). Because fertilizers are applied to crops 582 other than wheat and potatoes, the assessment can be extended to other routes of Cd transfer 583 from soils to food products of plant and animal origin. Moreover, other trace elements present in the soil can compete with Cd for uptake by plants (Dharma-wardana, 2018). Some of these 585 elements, namely $\mathrm{Zn}$ and Se, are known to interfere with Cd toxicity. For instance, $\mathrm{Zn}$ clearly 586 inhibits Cd uptake and bioavailability in many plant species (Chaney, 2012). A review of the 587 role of ion competition $(\mathrm{Cu}, \mathrm{Se}, \mathrm{Zn}$, etc.) on $\mathrm{Cd}$ toxicity and $\mathrm{Cd}$ uptake by plants suggests that 588 they depend on element concentrations and plant genotype (Qin et al., 2020). Furthermore, 589 Kikuchi et al. (2003) and JECFA (2004) stressed that the gastro-intestinal absorption of Cd is 590 influenced by Zn and other ions. Such interactions, inhibitions or synergies may influence the 
resulting toxicity. However, we here used as a reference point a HBGV set for cadmium, which

592 is based on epidemiological data (ANSES, 2019). Therefore, this HBGV includes the 593 interactions with other trace elements provided through the general consumer diet.

594 Nevertheless, the comparison of the effect of the studied scenarios on dietary exposure to $\mathrm{Cd}$ 595 remains valid. In addition, parameters related to climate, soil typology, agricultural practices, 596 agricultural inputs (particularly fertilizers of organic origin (which had large amounts of 597 missing data) and food habits were considered to be constant over the 99-year period because 598 the data to take into account the evolutions of these parameters were not available.

599 Because data on leaching in French agricultural soils were missing, Cd transfer via leachates 600 was estimated from an Australian environment using the equation derived in De Vries et al., 601 (2011, 2013). Sterckerman et al. (2018a) indicated that the accuracy of mass can be improved 602 with a better assessment of $\mathrm{Cd}$ leaching. Their study of six scenarios of agricultural practices 603 in France demonstrated the consequences of the calculated results on the proportion of leached 604 Cd in the mass balance, with different factors affecting the outflow of leached Cd (Sterckerman 605 et al., 2018a). However, in our study, the input data related to the calculation of Cd transfer via 606 leaching were based on a situation maximalist in the context of a health risk assessment.

607 Another difficulty was to estimate the real proportion of bioavailable $\mathrm{Cd}$ relative to the 608 application of fertilizers. Our models assumed that total $\mathrm{Cd}$ was fully bioavailable as a 609 conservative, protective hypothesis. Through soil characteristics ( $\mathrm{pH}$, carbonates, etc.) included 610 in transfer equations, $\mathrm{Cd}$ distribution was considered and then indirectly as $\mathrm{Cd}$ speciation. 611 However, Cd speciation actually depends on soil characteristics.

612 In fine, our approach is a predictive tool that can be used to propose safe and sanitary Cd levels 613 according to the $\mathrm{Cd}$ concentrations in a product placed on the market whose Cd content can be 614 controlled, or according to Cd fluxes regardless of fertilizer type and/or the total fertilisers 615 applied to arable soils. Through the combination of $\mathrm{Cd}$ concentration and fertilizer application 
616 dose as input data, reasoning finally in Cd fluxes is of interest to the farmer and the regulator,

617 regardless of the fertilizing materials used. The estimation of fluxes can quantitatively and

618 temporally monitor the Cd inputs with regard to the sustainable management of $\mathrm{Cd}$ inputs in

619 agricultural soils and crops in a context of agroecological transition.

620

6214.2 Recommendation of $\mathrm{Cd}$ limits in fertilizers to reduce soil, plant and related food chain

622 contamination

623 Our study examined the effects of actions to reduce the source of Cd inputs identified in

624 agricultural activities and over time. In support of a sustainable food system and in an effort to

625 preserve the environment, this study was at the interface of a risk assessment approach and

626 implementation of regulations with regard to putting EC-marked fertilizers on the market.

627 Ultimately, to reduce consumer exposure to $\mathrm{Cd}$, one efficient action is to reduce the Cd level of

628 a controlled product, such as mineral phosphate fertilizers, the main source of Cd inputs in

629 agricultural soils (Belon et al., 2012).

630 Our work simulated different $\mathrm{Cd}$ concentrations in commercial mineral phosphate fertilizers

631 based on protective fertilization plans applied in the case of French agricultural soils, for which

632 extensive field data is available in the RMQS. Our approach modelled the Cd effects on the

633 environment and consumer health by using different mineral phosphate fertilizations plans

634 playing different $\mathrm{Cd}$ concentrations $\left(90,60,40\right.$ or $20 \mathrm{mg} \mathrm{Cd} \cdot \mathrm{kg} \mathrm{P}_{2} \mathrm{O}_{5}{ }^{-1}$ as constant or degressive

635 over a 99-year period), giving Cd fluxes varying between 0.67 and $9 \mathrm{~g} \mathrm{Cd} . \mathrm{ha}^{-1} \cdot \mathrm{an}^{-1}$. In

636 comparison with a reference scenario using the French threshold $\left(90 \mathrm{mg} \mathrm{Cd} \cdot \mathrm{kg}_{2} \mathrm{O}_{5}{ }^{-1}\right)$, results

637 from our study showed the need to take measures to reduce $\mathrm{Cd}$ inputs at the source. In regard

638 to environmental and consumer safety, measures need to include restrictions on $\mathrm{Cd}$

639 concentrations, either by using the lowest possible concentration of $20 \mathrm{mg} \mathrm{Cd} \cdot \mathrm{kg}_{2} \mathrm{O}_{5}^{-1}$ in the

640 product commercialized or not exceeding flux of $2 \mathrm{~g} \mathrm{Cd}$. ha ${ }^{-1}$.year ${ }^{-1}$. Stabilization, and 
641 eventually a decrease in Cd levels in soils, plants and leachates over time was confirmed for $642 \mathrm{Ph} / 80 \mathrm{~b} / 20, \mathrm{Ph} / 100 \mathrm{~b} / 20, \mathrm{Ph} / 100 \mathrm{bp} / 20, \mathrm{Ph} / 180 \mathrm{bp} / 20$ fertilization plans using lowest $\mathrm{Cd}$ 643 concentration and the $\mathrm{Ph} / 80 \mathrm{~b} / 60-40-20, \mathrm{Ph} / 100 \mathrm{~b} / 60-40-20, \mathrm{Ph} / 100 \mathrm{bp} / 60-40-20, \mathrm{Ph} / 180 \mathrm{bp} / 60$ 644 40-20 fertilizations plans progressively reducing the $\mathrm{Cd}$ concentration in mineral phosphate 645 fertilizers to $20 \mathrm{mg} \mathrm{Cd} \cdot \mathrm{kg}_{2} \mathrm{O}_{5}{ }^{-1}$ over 15 years. These fertilization plans do not exceed a Cd 646 flux of $2{\mathrm{~g} \mathrm{Cd} . \mathrm{ha}^{-1} \text {.year }}^{-1}$. Dropping below this level appears essential to stop the increase in 647 the part of the population likely to be overexposed to $\mathrm{Cd}$ through food. Although results of 648 exposures exceeded the oral HBGV, those results showed that if no action is taken to reduce 649 the Cd content in mineral phosphate fertilizers, the risk will increase over time due to Cd 650 accumulation. Because fertilizers are applied to many crops and not only potatoes and wheat, 651 it is likely that the effects observed following a reduction of $\mathrm{Cd}$-containing fertilizer application 652 would have a favourable impact on all crops and consequently on dietary exposure.

653 Anyway, the application of mineral phosphate fertilizers with contents higher than $40 \mathrm{mg} \mathrm{Cd.kg}$ $654 \mathrm{P}_{2} \mathrm{O}_{5}{ }^{-1}$ (linked to $\mathrm{Cd}$ fluxes greater than $2 \mathrm{~g} \mathrm{Cd}$ ha $^{-1}$.year ${ }^{-1}$, see Table 1) is incompatible with 655 the typology of the receiving agricultural soil. A risk of $\mathrm{Cd}$ accumulation in soils is observed 656 through an analysis of soils characteristics on $\mathrm{Cd}$ transfer by the model. According to $\mathrm{Cd}$ 657 concentrations of 90, 60 and $40 \mathrm{mg}$ Cd.kg $\mathrm{P}_{2} \mathrm{O}_{5}{ }^{-1}$ in mineral phosphate fertilizer, our 658 probabilistic simulations showed great variation in the $\mathrm{Cd}$ concentration in soils based on a 659 variety of cases, including unfavourable and protective local situations (for example, soils low 660 in phosphorus requiring higher fertilization). According to soil characteristics (e.g. pH $>7$ ) and 661 soil uses (e.g. cultivated soils that are currently amended), Römkens et al. (2017) predict large 662 Cd accumulation which can exceed 30\% in soils: in that study, both the strong Cd fluxes and 663 high $\mathrm{pH}$ favour the soil pollution. In presence of alkaline soils, our results also indicated trends 664 of $\mathrm{Cd}$ to be immobilised by precipitation regardless of the $\mathrm{Cd}$ content of the mineral phosphate 665 fertilizers tested. As demonstrated by our simulation, the reduction in $\mathrm{Cd}$ at the source can be 
666 efficient even in acidic soils. In effect, the effect of $\mathrm{pH}$ on $\mathrm{Cd}$ bioavailability results in a

667 significant reduction in transfer in the presence of purified soil over the time, particularly at the 668 lowest $\mathrm{Cd}$ concentration in mineral phosphate fertilizers. Acidic soils favour the $\mathrm{Cd}$ transfer to 669 plants (Tremel-Schaub and Feix, 2005), thus they are considered as 'at-risk soils' in terms of 670 crops and therefore human exposure. We also observed a slightly more marked Cd transfer in 671 wheat grain than in potatoes, a crop that requires phosphorus. In potatoes, the phyto-available $672 \mathrm{Cd}$ fraction will be directly taken up and transferred to the tuber, whereas in wheat, there is less translocation of $\mathrm{Cd}$ from roots to grain. Rotational fertilization scenarios reduced $\mathrm{Cd}$ accumulation over time and $\mathrm{Cd}$ transfer to plants and leachates is more marked for a rotation 675 plan of $180 \mathrm{~kg} \mathrm{P} \mathrm{O}_{5} \cdot \mathrm{ha}^{-1}$.year ${ }^{-1}$ with a two-year pause in fertilisation, due to a lower annual Cd 676 input. Otherwise, a comparison of the mass balances showed that $\mathrm{Cd}$ transfer is greater in 677 leachates than in soil and plant matrices. These transfers to ground water and surface water contributing to diffuse and generalised environmental contamination must be limited as much as possible in light of the resulting environmental and health consequences. In addition, this water may be subsequently used for crop irrigation. Lowering Cd inputs via controlled fertilizer 681 application preserves the quality of the environment, specifically in regard to leaching water.

682 Our work opened by the comparison of modelling $\mathrm{Cd}$ inputs via mineral phosphate fertilizers 683 and other fertilising materials based on available data. For example, we modelled a wheat monoculture fertilization plan applied to French agricultural soils. Spreading sewage sludge, 685 cattle manure or anaerobic digestates, whose $\mathrm{Cd}$ concentration is low, can lead to a Cd flux of 686 up to $7.50 \mathrm{~g} \mathrm{Cd} . \mathrm{ha}^{-1}$ year $^{-1}$, due to a high amount of fertilizer applied to the soil. The comparison 687 indicated that irrespective of the type of fertilizer, a Cd flux of less than $2 \mathrm{~g} \mathrm{Cd} \mathrm{ha}^{-1}$.year ${ }^{-1}$ better 688 protected the environment (soil, plants) and consequently the related final food products.

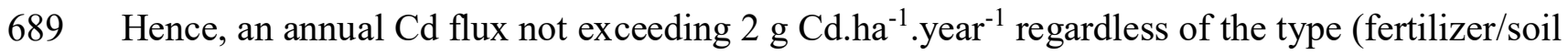
690 amendment, organic/mineral origin, etc.) and total quantity of fertilizer(s) added to French 
691 agricultural soils may help control the pollution of agricultural soils, contamination of

692 agricultural production and thus the associated dietary exposure. A Cd content equal to or less

693 than $20 \mathrm{mg} \mathrm{Cd} . \mathrm{kg} \mathrm{P}_{2} \mathrm{O}_{5}{ }^{-1}$ in mineral phosphate fertilizer products that can be regulated at the

694 source would ensure that this annual flux of $2 \mathrm{~g} \mathrm{Cd}^{-h^{-1}} \cdot \mathrm{year}^{-1}$ is not exceeded. Moreover 695 regarding human exposure to metals, given the growing urban populations around the world 696 and the frequent significant pollution events (Dumat et al., 2019; Natasha et al., 2019), it is 697 crucial to avoid insofar as possible the introduction of new persistent metals into the 698 environment and their accumulation in the food chain.

\section{$\underline{4.3 \text { How agroecology practices can promote human health }}$}

700 In France, the current standard threshold of $90 \mathrm{mg} \mathrm{Cd} \cdot \mathrm{kg} \mathrm{P}_{2} \mathrm{O}_{5}{ }^{-1}$ in mineral phosphate fertilizer

701 sustains the $\mathrm{Cd}$ contamination cycle and thus human $\mathrm{Cd}$ exposure, despite having taken steps

702 to limit $\mathrm{Cd}$ contamination by this fertilizer inputs. Currently, the new harmonized EU 703 Regulation (EU) 2019/1009 on the market of EU-labelled fertilizers is moving for that their 704 content of cadmium should therefore be limited in such products. This regulation establishes 705 that the $\mathrm{Cd}$ level in an organo-mineral fertilizer must not exceed $60 \mathrm{mg} \mathrm{Cd} \cdot \mathrm{kg} \mathrm{P}_{2} \mathrm{O}_{5}{ }^{-1}$. However, 706 maintaining a threshold of $60 \mathrm{mg} \mathrm{Cd} \cdot \mathrm{kg} \mathrm{P}_{2} \mathrm{O}_{5}{ }^{-1}$ does not stimulate a rapid reversal of the current 707 upward trend. Limiting applications to a concentration of $20 \mathrm{mg} \mathrm{Cd} \cdot \mathrm{kg} \mathrm{P}_{2} \mathrm{O}_{5}{ }^{-1}$ in an organo708 mineral fertilizer, perhaps in a degressive $\mathrm{Cd}$ decrease over a 15 -year period, would be more 709 beneficial and better protect the environment and human health.

710 Other ways (currently not explored for economic reasons) to promote soil quality is to select 711 phosphate rock deposits based on $\mathrm{Cd}$ concentration criteria and to optimise decadmiation 712 processes. Setting a limit on annual fluxes (equal or less to $2 \mathrm{~g} \mathrm{Cd} \mathrm{ha}^{-1}$.year ${ }^{-1}$ ) would be more 713 favourable for the management of fertilizer application and soil quality to obtain improvements.

714 Specifically, in France, the oldest threshold Cd fluxes stipulated in the existing national 715 regulations (instructions that accompany the MA application (guide No 50644\#01)) of $15 \mathrm{~g}$ 
716 Cd.ha ${ }^{-1} \cdot$ year $^{-1}$ (Ministère de l'Agriculture et de la Pêche, 2001) must be cut back by a factor of

7177 to reach the level we recommend here. Our recommendation of a threshold flux limit of $2 \mathrm{~g}$

$718 \mathrm{Cd}_{\mathrm{Cha}}{ }^{-1} \cdot \mathrm{year}^{-1}$ for applied fertilizers, regardless of their nature and quantity, would be more

719 efficient to control soil and plant contamination. This threshold is important for the last link in

720 the food chain: human consumers. This level would also be more convincing in France, for

721 which one-third of agricultural soils are at risk for cadmium accumulation (Delmas et al., 2015,

722 Saby et al., 2016).

723 The results showed that a Cd content below $1 \mathrm{mg} \mathrm{Cd} \cdot \mathrm{kg}^{-1}$ of dry matter (DM) in organic

724 fertilizers would comply with this flux of $2{\mathrm{~g} \mathrm{Cd} . \mathrm{ha}^{-1} \text {.year }}^{-1}$ (the mean Cd concentration is 0.7

725 mg. $\mathrm{kg}^{-1} \mathrm{DM}$ for farm anaerobic digestates). Although France has introduced a regulatory $\mathrm{Cd}$

726 threshold in digestate of $3 \mathrm{mg} \cdot \mathrm{kg}^{-1} \mathrm{DM}$ by a French decree of $13 \mathrm{June} 2017$, this limit is not

727 sufficient according to our simulations to reduce the accumulation of $\mathrm{Cd}$ in soils and crops, and

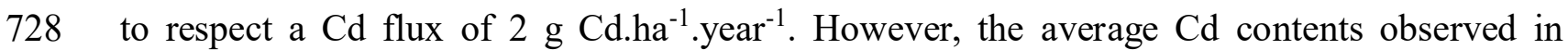

729 anaerobic digestion digestates in France $\left(0.7 \mathrm{mg} \cdot \mathrm{kg}^{-1} \mathrm{DM}\right)$ respect this flux. In view of the

730 difficulty of controlling Cd concentrations in organic fertilizers, providing a $\mathrm{Cd}$ limit in this

731 type of input source may lead to limitations on their agricultural reuse. Their redirection towards

732 other means of disposal or reuse methods (landfilling in storage centres, incineration, anaerobic

733 digestion, etc.) may also constitute sources of pollution that need to be controlled. The benefit

734 of reducing $\mathrm{Cd}$ concentrations in mineral phosphate fertilizers was particularly noted for acidic

735 soils, which promote $\mathrm{Cd}$ solubility and therefore phytoavailability. However, the $\mathrm{pH}$ of these

736 acidic soils can be increased by liming (adding alkaline soil amendments) to limit Cd transfer

737 to crops. Nevertheless, liming is not a sustainable alternative for avoiding Cd transfer to food.

738 Such liming practices have short-term benefits, but can represent a medium- and long-term

739 hazards, because there is no guarantee that the increase in $\mathrm{pH}$ will be sustainable. On the

740 contrary, the soil processes at work will tend to restore the original physico-chemical balances 
741 and lower the $\mathrm{pH}$ again, which in the long term may promote transfers from soil to crops and

742 leaching water. Liming cannot therefore be a substitute for an active policy of reducing Cd on 743 agricultural soils.

744 Given the temporary effectiveness of trapping techniques, it is necessary to continue to decrease 745 the limit value below $60 \mathrm{mg} \mathrm{Cd} \cdot \mathrm{kg} \mathrm{P}_{2} \mathrm{O}_{5}{ }^{-1}$ for mineral phosphate fertilizers (towards a value 746 equal to or lower than $20 \mathrm{mg} \mathrm{Cd} \cdot \mathrm{kg}_{2} \mathrm{O}_{5}^{-1}$ ) and the development of decadmiation techniques 747 relating to their production. The introduction of $\mathrm{Cd}$ fluxes limits or reduces Cd fluxes with 748 respect to the French administrative guidance value (Ministère de l'Agriculture et de la Pêche, 749 2001), enhancing the management of $\mathrm{Cd}$ inputs into soils on a larger scale.

750 Given this ubiquitous contaminant, limiting fluxes will be more effective when combined with 751 the reduction of the contamination cycle by controlling $\mathrm{Cd}$ inputs of all fertilizers and by 752 reducing the contribution of all other types of inputs.

753 Sterckerman et al. (2018 a and b) observed that an over-fertilization of agricultural crops can 754 induce long-term $\mathrm{Cd}$ accumulation in French soils. They highlighted that soil quality can be 755 improved with a combination of good practices regarding phosphate fertilization and limiting 756 Cd content in mineral phosphate fertilizers, along with a progressive decrease in Cd content in 757 mineral phosphate fertilizers consistent with the proposal related to the revision of the EU 758 fertilizer regulation. Their study indicated that the use of organic farming and fertilizers of 759 organic origin can also lead to an evolution of cadmium in the soil in a similar way to that of 760 conventional agriculture by applying good practices.

761 To promote sustainable agriculture and the agri-food system at the global scale, both improving 762 the quality of fertilizers and amendments and optimising the applied quantities (considering the 763 plant cycle, using green manure crops and other agroecological practices) are therefore crucial 764 steps. The development of numerous urban agriculture projects involving different stakeholders 
constitutes an efficient vector for ecology education and enhances the links between consumers and local and organic produce farmers (Dumat, 2019).

\section{Conclusions and perspectives}

769 Cd combined hazard and exposure characteristics support the importance of health assessment

770 work focused on exposure to this substance.

771 To preserve human health, reducing $\mathrm{Cd}$ exposure is recommended, by acting in particular on 772 the level of environmental contamination, especially via mineral phosphate fertilizers and more 773 widely via all fertilizing materials. Results derived from our predictive model provide a

774 scientific support for environmental management and public policy decision-making. At the 775 interface of applied research, risk assessment, expert assessment and regulatory decision776 making, the proposed model based on a mass-balance approach made it possible to determine 777 the maximum $\mathrm{Cd}$ level in mineral phosphate fertilizers to control and reduce $\mathrm{Cd}$ soil pollution, 778 crop contamination and dietary exposure in consumers, as well as occupational exposure (albeit indirect) in the fertilizer industry. Perspectives for research include a better understanding and

780 more data on leachates, phytoavailability, $\mathrm{Cd}$ speciation and characterisation of organic 781 fertilizers.

782 Moreover, our model can be extended to other countries using their data and fertilization plans.

783 It can be also a tool for further studies and be extended to the assessment of other contaminants

784 identified in polluted sites and soils.

785 Given the ubiquitous nature of $\mathrm{Cd}$ and the need to reduce its environmental contamination cycle 786 and long-term dietary exposure to this element, it is important to control Cd fluxes via 787 fertilizers. A Cd flux lower than $2 \mathrm{~g} \mathrm{Cd} \cdot \mathrm{ha}^{-1} \cdot \mathrm{year}^{-1}$ from the application of fertilizers, 788 corresponding to a $\mathrm{Cd}$ content of $20 \mathrm{mg} \cdot \mathrm{kg}_{2} \mathrm{O}_{5}{ }^{-1}$ or less in mineral phosphate fertilizers, 789 ensures better protection of environmental and human health. Within a century, a protective 
790 concentration of 20 mg.kg $\mathrm{P}_{2} \mathrm{O}_{5}{ }^{-1}$ in a potato/wheat/wheat rotation fertilizer plan of $180 \mathrm{~kg}$

$791 \mathrm{P}_{2} \mathrm{O}_{5} \cdot \mathrm{ha}^{-1}$.year ${ }^{-1}$ with a two-year no-fertiliser period can lead to a mean Cd reduction of up to $79217 \%$ in French agricultural soils, $18 \%$ in wheat grain, $14 \%$ in potatoes and $21 \%$ in leachates.

793 This reduction is essential to limit $\mathrm{Cd}$ accumulation in soils such that consumer exposure,

794 mainly via food, does not exceed the health threshold values.

795

796 Acknowledgements

797 We are grateful to the ANSES Expert Panels on "Health reference values", "Fertilizers and 798 growing media" and "Assessment of the physical and chemical risks in foods" for proofreading 799 and validating this work. We are grateful to the INFOSOL-INRAE research unit for providing 800 and authorising the use of French soil data.

801

802

803

804

805

806

807

808

809

810

811

812

813

814 
817 ANSES. 2011a. Avis de l'ANSES et rapport d'expertise relatifs à l'Etude de l'Alimentation 818 Française 2 (EAT2) - Tome 1 : Contaminants inorganiques, minéraux, poluants organiques 819 persistants, mycotoxines, phyto-estrogènes, Agence nationale de sécurité sanitaire de 820 l'alimentation, de l'environnement et du travail, Maisons-Alfort. 821 https://www.anses.fr/fr/system/files/PASER2006sa0361Ra1.pdf

ANSES. 2011b. Avis de l'ANSES relatif à la révision des teneurs maximales en cadmium des 824 denrées alimentaires destinées à 1'homme. (saisine n²011-SA-0194), Agence nationale de 825 sécurité sanitaire de l'alimentation, de l'environnement et du travail, Maisons-Alfort. 826 https://www.anses.fr/fr/system/files/RCCP2011sa0194.pdf.

ANSES. 2016. Avis et rapport de l'ANSES relatif à l'exposition alimentaire des enfants de 829 moins de 3 ans à certaines substances - Etude de l'Alimentation Totale Infantile (EAT 830 infantile). https://www.anses.fr/fr/content/etude-de-1\%E2\%80\%99alimentation-totale-infantile

832 ANSES. 2019. Avis et rapports de l'ANSES relatif à l'exposition au cadmium (CAS nº7440833 43-9). https://www.anses.fr/fr/content/exposition-au-cadmium-1\%E2\%80\%99anses-propose834 des-valeurs-limites-pour-mieux-prot $\% \mathrm{C} 3 \%$ A9ger-les

836 Arrouays D., Jolivet C., Boulonne L., Bodineau G., Saby N., Grolleau E. 2002. A new initiative 837 in France: a multi-institutional soil quality monitoring network. Comptes Rendus de 838 l'Académie d'Agriculture de France, 88 (2002), pp. 93-105 
840 Arrouays D., Richer-de-Forges A-C., Héliès F., Mulder V. L., Saby N., Chen S., Martin M.,

841 Dobarco M. R., Follain S., Jolivet C., Laroche B., Loiseau T., Cousin I., Lacoste M., Ranjard

842 L., Toutain B., Le Bas C., Eglin T., Bardy M., Antoni V., Meersmans J., Ratié C., Bispo A.

843 2020. Impacts of national scale digital soil mapping programs in France, Geoderma Regional,

844 Volume 23, 2020, e00337, ISSN 2352-0094, https://doi.org/10.1016/j.geodrs.2020.e00337.

845

846 ARVALIS. 2011. Les 3 étapes du pilotage de l'irrigation, ARVALIS - Institut du Végétal, Paris

847 https://www.arvalis-infos.fr/guide-de-production-de-la-pomme-de-terre-@/view-11974-

$848 \quad$ arvarticle.html

849

850 ARVALIS. 2013. Fiches Variétés blé tendre, blé dur, orges et pommes de terre, ARVALIS -

851 Institut $\quad$ du égétal, $\quad$ Paris $\quad$ http://www.fiches.arvalis-

852 infos.fr/liste fiches.php? fiche $=$ var\&type $=001$

853

854 ARVALIS. 2018. Le raisonnement de la fertilisation P-K repose sur quatre critères, ARVALIS

855 - Institut du Végétal, Paris https://www.arvalis-infos.fr/le-raisonnement-de-la-fertilisation-p-k-

856 repose-sur-quatre-criteres-@/view-240-arvarticle.html

857

858 Belon E., Boisson M., Déportes IZ., Eglin TK., Feix I., Bispo AO., Galsomies L., Leblond S.,

859 Guellier C. R. 2012. An inventory of trace elements inputs to French agricultural soils. Science

860 of The Total Environment 439:87-95. http://dx.doi.org/10.1016/j.scitotenv.2012.09.011

861

862 Benoît P., Brugère H., Casellas M., Dabert P., Fuchs J., Giamberini L., et al. 2014. ESCo

863 "Matières fertilisantes d'origine résiduaire". Caractéristiques physico-chimiques et biologiques

864 des Mafor. Rapport final de l'expertise collective. Chapitre 2. 2014: 212. https://inra-dam-front- 
866 chapitre-2.html

867

868 Birke, M., Reimann, C., Rauch, U., Ladenberger, A., Demetriades, A., Jähne-Klingberg, F.,\& 869 Team, T. G. P. 2017. GEMAS: Cadmium distribution and its sources in agricultural and grazing 870 land soil of Europe - Original data versus clr-transformed data. Journal of geochemical 871 exploration, 173, 13-30. http://dx.doi.org/10.1016/j.gexplo.2016.11.007

873 Brittany Chamber of Agriculture SNCVA, Cemagref. 2007. Les bonnes pratiques d'épandage 874 du fumier. 2007: 29 pages. Guide disponible : 875 http://www.synagri.com/ca1/PJ.nsf/TECHPJPARCLEF/08890/\$File/bonnes\%20pratiques\%2 $876 \quad$ 0epandage $\% 20$ FUMIER.pdf?OpenElement

877

878 Chaney, R. L. 2012. Chapter 2: Food safety issues for mineral and organic fertilizers. Advances 879 in Agronomy, 117, 51-116

880

881 COMIFER, 2009. Fertilisation PK. Grille de calcul de dose, Paris. 882 https://comifer.asso.fr/images/publications/livres/tablesexportgrillescomifer2009.pdf 883

884 COMMISSION REGULATION (EC) No 1881/2006 of 19 December 2006 setting maximum 885 levels for certain contaminants in foodstuffs. https://eur-lex.europa.eu/legal886 content/EN/ALL/?uri=CELEX\%3A32006R1881 
888 Delmas, M., Saby, N., Arrouays, D., Dupas, R., Lemercier, B., Pellerin, S., \& Gascuel- Odoux, 889 C. 2015 . Explaining and mapping total phosphorus content in French topsoils. Soil use and 890 management, 31(2), 259-269. https://doi.org/10.1111/sum.12192

891

892 De Vries., McLaughlin., Groenenberg. 2011. Transfer functions for solide-solution partitioning 893 of cadmium for Australian soils. Environmental Pollution 159 (2011) 3583-3594. 894 http://dx.doi:10.1016/j.envpol.2011.08.006

895

896 De Vries., McLaughlin., 2013. Modeling the cadmium balance in Australian agricultural 897 systems in view of potential impacts on food and water quality. Science of the Total 898 Environment 461-462 (2013) 240-257. http://dx.doi.org/10.1016/j.scitotenv.2013.04.069

899

900 Dharma-wardana M. W. C. 2018. Fertilizer usage and cadmium in soils, crops and food, Env. 901 Geochem Heath, https://doi.org/10.1007/s10653-018-0140-x

902

903 Dubuisson, C., Lioret, S., Touvier, M., Dufour, A., Calamassi-Tran, G., Volatier, J.L., Lafay, 904 L., 2010. Trends in food and nutritional intakes of French adults from1999 to 2007: results from 905 the INCA surveys. Brit. J. Nutr. 103, 1035-1048. doi:10.1017/S0007114509992625 906

907 Dumat C., Pierart A., Shahid M., Khalid S., 2019. Pollutants in urban agriculture: sources, 908 health risk assessment and sustainable management. Chapitre d'ouvrage. in "Bioremediation of 909 Agricultural Soils”, CRC press Taylor \& Francis Group. 2019. Coordination par PD Sanchez. 910

911 Dumat C. 2019. Chapitre d'ouvrage in Carrère, G., Dumat, C., Zélem, M.-C. (Ed). 2019.

912 L'Harmattan. Collection Sociologies et environnement, 324 pages, ISBN 978-2-343-15110-6. 
913 Dans la fabrique des transitions écologiques : Permanence et changements. L'agriculture

914 urbaine : un vecteur de dynamiques sociales inclusives pour l'écologisation des systèmes

915 alimentaires ?

916

917 European Commission. 2016. Limits for cadmium in phosphate fertilizers. Accompanying the

918 document Proposal for a Regulation of the European Parliament and of the Council laying down

919 rules on the making available on the market of CE marked fertilizing products and amending.

920 Ref.Ares(2016)1341463-17/03/2016

921 https://ec.europa.eu/transparency/regdoc/rep/1/2016/EN/1-2016-157-EN-F1-1.PDF

922

923 European Food Safety Authority, EFSA. 2009. Cadmium in food. Scientific Opinion of the

924 Panel on Contaminants in the Food Chain. The EFSA Journal 980, 1-139.

925 https://doi.org/10.2903/j.efsa.2009.980

926

927 European Food Safety Authority, EFSA. 2012. Cadmium dietary exposure in the European

928 population. EFSA Journal 2012;10(1):2551. [37 pp.] doi:10.2903/j.efsa.2012.2551

929

930 FOREGS. 2005. Geochemical Atlas of Europe. Part 1-Background information,

931 methodology, and maps, Forum of the European Geological Surveys (FOREGS). Geological

932 Survey of Finland, Espoo. http://weppi.gtk.fi/publ/foregsatlas/index.php

933

934 FOREGS. 2006. Geochemical Atlas of Europe. Part 2-Interpretation of geochemical maps,

935 additional tables, figures, maps and related publications, Forum of the European Geological

936 Surveys (FOREGS). Geological Survey of Finland, Espoo.

937 http://weppi.gtk.fi/publ/foregsatlas/part2.php 
939 Franz E, Römkens P, van Raamsdonk L, Fels-Klerx Vd. 2008. A chain modeling approach to 940 estimate the impact of soil cadmium pollution on human dietary exposure. Journal of Food

941 Protection 2008; 71: 2504-2513. https://doi.org/10.4315/0362-028X-71.12.2504

942

943 IARC, International Agency for Research on Cancer. 2012. Cadmium. Vol 100C.121-145.

944

945 IRSTEA, SOLAGRO. 2012. Etat de l'art des digestats et leur procédés de post traitement (projet 946 DIVA). Porojet ANR - 10 - BIOE - 007 2012; Livrables 2.1, 2.2, 2.3, 3.1: 76pp. Disponible :

947 https://diva.irstea.fr/livrables/.

948

949 Jean J., Sirot V., Vasseur P., Narbonne J-F., Leblanc J-C., Volatier J-L., Rivière G. 2015. 950 Impact of a modification of food regulation on cadmium exposure. Regulatory Toxicology and 951 Pharmacology 73 (2015) 478e483. http://dx.doi.org/10.1016/j.yrtph.2015.07.027

953 JECFA. 2004. Safety evaluation of certain food additives and contaminants. 61st Report of the 954 Joint FAO/WHO Expert Committee on Food Additives and Contaminants. WHO, Geneva, 955 2004. https://apps.who.int/iris/handle/10665/42849

956

957 Kikuchi Y., Nomiyama T., Kumagai N., Dekio F., Uemura T., Takebayashi T., et al. 2003. 958 Uptake of cadmium in meals from the digestive tract of young nonsmoking Japanese female 959 volunteers. J Occup Health 2003: 45(1): 43-52. https://doi.org/10.1539/joh.45.43| 960

961 Lioret, S., Dubuisson, C., Dufour, A., Touvier, M., Calamassi-Tran, G., Maire, B., Volatier, 962 J.L., Lafay, L., 2010. Trends in food intake in French children from 1999 to 2007: results from 
963 the INCA (étude Individuelle Nationale des Consommations Alimentaires) dietary surveys. Br.

964 J. Nutr. 103, 585-601. doi:10.1017/S0007114509992078

965

966 Marchant, B. P., Saby, N. P. A., Lark, R. M., Bellamy, P. H., Jolivet, C. C., \& Arrouays, D. 967 2010. Robust analysis of soil properties at the national scale: cadmium content of French soils. 968 European Journal of Soil Science, 61(1), 144-152. doi: 10.1111/j.1365-2389.2009.01212.x

969

970 Millour S, Noël L, Kadar A, Chekri R, Vastel C, Sirot V, Leblanc JC, Guérin T. 2011. Pb, Hg, $971 \mathrm{Cd}, \mathrm{As}, \mathrm{Sb}$ and Al levels in Foodstuffs from the 2nd French Total Diet Study. Food Chem 126: 972 1787-1799. doi: 10.1016/j.foodchem.2010.12.086

973

974 Ministère de l'Agriculture et de la Pêche, 2001. Guide pour la constitution des dossiers de 975 demande d'homologation des matières fertilisantes et des supports de culture. Formulaire 976 CERFA n50644\#01. https://www.anses.fr/fr/system/files/DIVE-ft-cerfa50644.pdf

978 Natasha, Dumat C., Shahid M., Khalid S., Murtaza B., 2019. Chapitre d'ouvrage in Lead in 979 Plants and the Environment, Gupta, Dharmendra K., Chatterjee, Soumya, Walther, Clemens 980 (Eds.), ISBN 978-3-030-21637-5. Part of the Radionuclides and Heavy Metals in the 981 Environment book series (RHME). Lead Pollution and Human Exposure: Forewarned is 982 Forearmed, and the Question Now Becomes How to Respond to the Threat! pp 33-65. 983

984 Plateau A 2001. Effluents d'élevage - Elaboration d'un référentiel national, Paramètres 985 agronomiques classiques et éléments traces métalliques des effluents d'élevage bovin, ovin et 986 caprin. Rapport de stage de fin d'étude d'ingénieur Ecole Supérieure d'Agriculture d'Angers; 9872001. 
989 Qin S.Y., Liu H. E., Nie Z.J., Rengel Z., Gao W., Li C., Zhao P. 2020. Toxicity of cadmium 990 and its competition with mineral nutrients for uptake by plants: A review. Pedosphere. 30 (2): 991 168-180. https://doi.org/10.1016/S1002-0160(20)60002-9

992

993 Ran J., Wang D., Wang C., Zhang G., Zhang H. 2016. Heavy metal contents, distribution, and 994 prediction in a regional soil-wheat system. Science of The Total Environment 2016; 544: 422995 431. http://dx.doi.org/10.1016/j.scitotenv.2015.11.105

996

REGULATION (EC) n 2003/2003 OF THE EUROPEAN PARLIAMENT AND OF THE 998 COUNCIL of 13 October 2003 relating to fertilizers. https://eur-lex.europa.eu/legal999 content/GA/TXT/?uri=CELEX:32003R2003

1000

REGULATION (EU) 2019/1009 OF THE EUROPEAN PARLIAMENT AND OF THE

COUNCIL of 5 June 2019 laying down rules on the making available on the market of EU

1003 fertilising products and amending Regulations (EC) No 1069/2009 and (EC) No 1107/2009.

1004 https://eur-lex.europa.eu/legal-content/EN/TXT/?uri=CELEX\%3A32019R1009

1005

1006 Rietra, R.P.J.J., G. Mol, I.M.C.M Rietjens, and P.F.A.M Römkens. 2017. Cadmium in soils, 1007 crops, and resultant dietery exposure. Wageningen, Wageningen Environmental Research, 1008 Report 2784, 40 pp., 7 fig., 14 tab., 74 ref. http://dx.doi.org/10.18174/403611

1010 Roberts, T. L. 2014. Cadmium and phosphorous fertilizers: the issues and the science. Procedia 1011 Engineering, 83, 52-59. http://dx.doi:10.1016/j.proeng.2014.09.012 
1013 Römkens P., De Vries W. and Kros H. 2017. Dynamic Cadmium balances in arable soils and

1014 grassland soils in the EU: impact of revision of fertilizer regulation on accumulation rates and

1015 levels of Cd in soils - preliminary results as of June 14, 2017 - Wageningen Environmental

1016 Research (Alterra) https://cdn2.hubspot.net/hubfs/2828618/downloads/dynamic-cadmium-

1017 balances-in-arable-soils-and-grassland-soils-in-the-eu.pdf

1018

1019 Saby, N., Gouny, L., Lemercier, B., Denoroy, P., \& Eveillard, P. 2016. Utilisation des données

1020 de la BDAT pour étudier l'évolution spatio-temporelle des teneurs en Magnésium échangeable,

1021 Potassium échangeable et Phosphore extractible dans les sols agricoles de France

1022 métropolitaine. 90p (in French) https://hal.archives-ouvertes.fr/hal-01581567/document

1023

1024 Saby, N., Bertouy, B. Boulonne, L., Bispo, A. Ratié, C., Jolivet, C.. 2019. Statistiques

1025 sommaires issues du RMQS sur les données agronomiques et en éléments traces des sols

1026 français de 0 à $50 \mathrm{~cm}$. doi:10.15454/BNCXYB

1027

1028 Six L., Smolders E. 2014. Future trends in soil cadmium concentration under current cadmium

1029 fluxes to European agricultural soils. Science of the Total Environment 485-486 (2014) 319-

1030 328. http://dx.doi.org/10.1016/j.scitotenv.2014.03.109

1031

1032 Shahid M., Dumat C., Khalid S., Niazi N., Antunes P. 2017. Cadmium Bioavailability, Uptake,

1033 Toxicity and Detoxification in Soil-Plant System. Rev Environ Contam Toxicol (241), 73-137.

1034 DOI: $10.1007 / 398 \_2016 \_8$

1035 
1036 Sterckeman T., Gossiaux L., Guimont S., Sirguey C., Lin Z. 2018a. Cadmium mass balance in

1037 French soils under annual crops: Scenarios for the next century. Science of the Total 1038 Environment 639 (2018) 1440-1452. https://doi.org/10.1016/j.scitotenv.2018.05.225

1039

1040 Sterckeman T., Gossiaux L., Guimont S., Sirguey C., Lin Z. 2018b. Corrigendum to “Cadmium 1041 mass balance in French soils under annual crops: Scenarios for the next century” [Sci. Total 1042 Environ. 639 (2018) 1440-1452]. https://doi.org/10.1016/j.scitotenv.2018.05.225

1043

1044 Tremel-Schaub A., Feix I. 2005. Contamination des sols : transfert des sols vers les plantes. 1045 EDP Sciences.

1046 https://laboutique.edpsciences.fr/produit/311/9782759802616/Contamination\%20des\%20sols 1047

1048 WHO. 2013. Reliable evaluation of low-level contamination of food. Addendum of the report 1049 on GEMS/Food-EURO second workshop of the 26-27th May 1995 1050 ftp://ftp.ksph.kz/Chemistry_Food\%20Safety/TotalDietStudies/Reliable.pdf

1052 Wolf Environnement S, SAS. 2001. Bilan entre micropolluants organiques, éléments traces 1053 métalliques, paramètres agronomiques, $\mathrm{pH}$ et matière sèche des boues de station d'épuration 1054 d'effluents urbains (données de Janvier 1998 à avril 2000)._In: 2001. CA-j, editor, 2001. 1055 https://www.ademe.fr/sites/default/files/assets/documents/57992_sogreah.pdf 
Géraldine CARNE

Risk Assessment Department,

French Agency for Food, Environmental and Occupational Health \& Safety,

14 rue Pierre et Marie Curie, 94701 Maisons-Alfort Cedex

FRANCE

Title of the manuscript: " Mass balance approach to assess the impact of cadmium decrease in mineral phosphate fertilizers on health risk: the case-study of French agricultural soils".

Authors: G. Carne, S. Leconte, V. Sirot, N. Breysse, P-M Badot, A. Bispo, I.Z Deportes, C. Dumat, G.

Rivière, A. Crépet

List of Tables:

- Table 1. Representative and protective scenarios of mineral phosphate fertilizer inputs with regard to cadmium contamination in French agricultural soils, used for wheat monoculture crops or potato/wheat/wheat crop rotations

- Table 2. Mean percentage (\%) variation in Cd concentration in matrices (soil, wheat grain/or potatoes and leachate) over a 99-year period (10, 20, 60 and 99 years) compared with the first year of application of the mineral phosphate fertilizer with a control $\mathrm{Cd}$ content $(90,60,40$ and $\left.20 \mathrm{mg} \cdot \mathrm{kg}^{-1} \mathrm{P}_{2} \mathrm{O}_{5}\right)$ as a function of the phosphate fertilization plan

- Table 3. Cd inputs related to applications of organic fertilizers tested in the model 
Table 1. Representative and protective scenarios of mineral phosphate fertilizer inputs with regard to cadmium contamination in French agricultural soils, used for wheat monoculture crops or potato/wheat/wheat crop rotations

\begin{tabular}{|c|c|c|c|c|c|}
\hline & $\begin{array}{c}\text { Phosphate } \\
\text { fertilization plan } \\
(\mathrm{Ph}) \text { scenario } \\
(\mathrm{Ph} / \text { fertilizer } \\
\text { dose/Cd level) }\end{array}$ & $\begin{array}{c}\text { Quantity of } \\
\text { fertilizer } \\
\text { applied } \\
\left(\mathrm{kg} \mathrm{P}_{2} \mathrm{O}_{5} \cdot \mathrm{ha}^{-1}\right)\end{array}$ & $\begin{array}{l}\mathrm{Cd} \\
\text { concentration in } \\
\text { fertilizer (mg.kg } \\
\left.\mathrm{P}_{2} \mathrm{O}_{5-}{ }^{1}\right)\end{array}$ & $\begin{array}{l}\text { Cd inflow to the } \\
\text { soil }\left(\mathrm{g}^{-h^{-1}}\right)\end{array}$ & $\begin{array}{l}\text { Annual Cd flux } \\
\left(\mathrm{g} \cdot \mathrm{ha}^{-1} \cdot \text { year }^{-1}\right)\end{array}$ \\
\hline \multirow{7}{*}{$\begin{array}{l}\text { Annual application for } \\
\text { wheat monoculture }\end{array}$} & $\underline{\mathrm{Ph} / 80 \mathrm{~b} / 90}$ & \multirow{7}{*}{80} & 90 & 7.20 & 7.20 \\
\hline & $\mathrm{Ph} / 80 \mathrm{~b} / 60$ & & 60 & 4.80 & 4.80 \\
\hline & $\mathrm{Ph} / 80 \mathrm{~b} / 40$ & & 40 & 3.20 & 3.20 \\
\hline & $\mathrm{Ph} / 80 \mathrm{~b} / 20$ & & 20 & 1.60 & 1.60 \\
\hline & \multirow{3}{*}{$\mathrm{Ph} / 80 \mathrm{~b} / 60-40-20 *$} & & $60($ Year 1-3) & $4.80($ Year 1-3) & $4.80($ Year 1-3) \\
\hline & & & 40 (Year 4-15) & $3.20($ Year 4-15) & $3.20($ Year 4-15) \\
\hline & & & 20 (Year 16-99) & $1.60($ Year 16-99) & 1.60 (Year 16-99) \\
\hline \multirow{7}{*}{$\begin{array}{c}\text { Application every three } \\
\text { years for wheat } \\
\text { monoculture }\end{array}$} & $\underline{\mathrm{Ph} / 100 \mathrm{~b} / 90}$ & \multirow{7}{*}{100} & 90 & 9 & 3 \\
\hline & $\mathrm{Ph} / 100 \mathrm{~b} / 60$ & & 60 & 6 & 2 \\
\hline & $\mathrm{Ph} / 100 \mathrm{~b} / 40$ & & 40 & 4 & 1.33 \\
\hline & $\mathrm{Ph} / 100 \mathrm{~b} / 20$ & & 20 & 2 & 0.67 \\
\hline & \multirow{3}{*}{$\mathrm{Ph} / 100 \mathrm{~b} / 60-40-20 *$} & & $60($ Year 1-3) & $6($ Year 1-3) & 2 (Year 1-3) \\
\hline & & & $40($ Year 4-15) & 4 (Year 4-15) & 1.33 (Year 4-15) \\
\hline & & & 20 (Year 16-99) & 2 (Year 16-99) & 0.67 (Year 16-99) \\
\hline \multirow{5}{*}{$\begin{array}{c}\text { Annual application for a } \\
\text { potato/wheat/wheat } \\
\text { rotation }\end{array}$} & $\underline{\mathrm{Ph} / 100 \mathrm{bp} / 90}$ & \multirow{5}{*}{100} & 90 & 9 & 9 \\
\hline & $\mathrm{Ph} / 100 \mathrm{bp} / 60$ & & 60 & 6 & 6 \\
\hline & $\mathrm{Ph} / 100 \mathrm{bp} / 40$ & & 40 & 4 & 4 \\
\hline & $\mathrm{Ph} / 100 \mathrm{bp} / 20$ & & 20 & 2 & 2 \\
\hline & $\begin{array}{c}\mathrm{Ph} / 100 \mathrm{bp} / 60-40- \\
20^{*}\end{array}$ & & $\begin{array}{c}60(\text { Year } 1-3) \\
40(\text { Year } 4-15) \\
20(\text { Year } 16-99)\end{array}$ & $\begin{array}{c}6(\text { Year 1-3) } \\
4(\text { Year 4-15) } \\
2(\text { Year 16-99) }\end{array}$ & $\begin{array}{c}6(\text { Year 1-3) } \\
4(\text { Year 4-15) } \\
2(\text { Year 16-99) }\end{array}$ \\
\hline \multirow{7}{*}{$\begin{array}{c}\text { Application every three } \\
\text { years for a } \\
\text { potato/wheat/wheat } \\
\text { rotation }\end{array}$} & $\underline{\mathrm{Ph} / 180 \mathrm{bp} / 90}$ & \multirow{7}{*}{180} & 90 & 16.20 & 5.40 \\
\hline & $\mathrm{Ph} / 180 \mathrm{bp} / 60$ & & 60 & 10.80 & 3.60 \\
\hline & $\mathrm{Ph} / 180 \mathrm{bp} / 40$ & & 40 & 7.20 & 2.40 \\
\hline & $\mathrm{Ph} / 180 \mathrm{bp} / 20$ & & 20 & 3.60 & 1.20 \\
\hline & \multirow{3}{*}{$\begin{array}{c}\mathrm{Ph} / 180 \mathrm{bp} / 60-40- \\
20^{*}\end{array}$} & & $60($ Year 1-3) & $3.60($ Year 1-3) & 3.60 (Year 1-3) \\
\hline & & & $40($ Year 4-15) & 7.20 (Year 4-15) & $2.40($ Year 4-15) \\
\hline & & & 20 (Year 16-99) & 10.80 (Year 16-99) & 1.20 (Year 16-99) \\
\hline
\end{tabular}

Underlined: reference scenarios

$37 *$ : degressive cadmium concentration scenarios modelled over a 99-year period 
Table 1. Mean percentage (\%) variation in $\mathrm{Cd}$ concentration in matrices (soil, wheat grain/or 39 potatoes and leachate) over a 99-year period (10, 20,60 and 99 years) compared with the first 40 year of application of the mineral phosphate fertilizer with a control Cd content $(90,60,40$ and $4120 \mathrm{mg} \cdot \mathrm{kg}^{-1} \mathrm{P}_{2} \mathrm{O}_{5}$ ) as a function of the phosphate fertilization plan

\begin{tabular}{|c|c|c|c|c|c|c|c|c|c|c|c|c|c|c|c|c|}
\hline \multirow{5}{*}{$\begin{array}{l}\text { Phosphate } \\
\text { fertilization } \\
\text { plan }\end{array}$} & \multicolumn{16}{|c|}{ Matrix } \\
\hline & \multirow{2}{*}{\multicolumn{4}{|c|}{ Soil }} & \multicolumn{8}{|c|}{ Crop plant } & \multirow{2}{*}{\multicolumn{4}{|c|}{ Leachate }} \\
\hline & & & & & \multicolumn{4}{|c|}{ Wheat grain } & \multicolumn{4}{|c|}{ Potato tuber } & & & & \\
\hline & \multicolumn{4}{|c|}{$\begin{array}{l}\text { Period } \\
\text { (year) }\end{array}$} & \multicolumn{4}{|c|}{$\begin{array}{c}\text { Period } \\
\text { (year) }\end{array}$} & \multicolumn{4}{|c|}{$\begin{array}{c}\text { Period } \\
\text { (year) }\end{array}$} & \multicolumn{4}{|c|}{$\begin{array}{c}\text { Period } \\
\text { (year) }\end{array}$} \\
\hline & 10 & 20 & 60 & 99 & $10 / 11$ & 20 & 60 & 99 & 10 & 22 & 61 & 97 & 10 & 20 & 60 & 99 \\
\hline$\underline{\mathrm{Ph} / 80 \mathrm{~b} / 90}$ & +7 & +14 & +40 & +61 & +7 & +15 & +42 & +64 & - & - & - & - & +15 & +22 & +49 & +72 \\
\hline $\mathrm{Ph} / 80 \mathrm{~b} / 60$ & +4 & +7 & +21 & +32 & +4 & +8 & +22 & +34 & - & - & - & - & +11 & +15 & +29 & +42 \\
\hline $\mathrm{Ph} / 80 \mathrm{~b} / 40$ & +2 & +3 & +9 & +15 & +2 & +3 & +10 & +15 & - & - & - & - & +8 & +11 & +18 & +23 \\
\hline $\mathrm{Ph} / 80 \mathrm{~b} / 20$ & -1 & -1 & -3 & -4 & -1 & -1 & -3 & -4 & - & - & - & - & +7 & +6 & +4 & +3 \\
\hline $\begin{array}{c}\mathrm{Ph} / 80 \mathrm{~b} / 60-40- \\
20 *\end{array}$ & +2 & +2 & 0 & -2 & +2 & +2 & 0 & -2 & - & - & - & - & +10 & +7 & +6 & +6 \\
\hline$\underline{\mathrm{Ph} / 100 \mathrm{~b} / 90}$ & +1 & +2 & +6 & +11 & +1 & +2 & +7 & +11 & - & - & - & - & +8 & +10 & +16 & +19 \\
\hline $\mathrm{Ph} / 100 \mathrm{~b} / 60$ & 0 & -1 & -1 & 0 & 0 & -1 & -1 & 0 & - & - & - & - & +7 & +7 & +6 & +7 \\
\hline $\mathrm{Ph} / 100 \mathrm{~b} / 40$ & -1 & -2 & -6 & -8 & -1 & -2 & -6 & -8 & - & - & - & - & +5 & +5 & +2 & -1 \\
\hline $\mathrm{Ph} / 100 \mathrm{~b} / 20$ & -2 & -4 & -11 & -15 & -2 & -4 & -11 & -16 & - & - & - & - & +5 & +3 & -5 & -7 \\
\hline $\begin{array}{c}\mathrm{Ph} / 100 \mathrm{~b} / 60-40- \\
20 * \\
\end{array}$ & -1 & -3 & -9 & -14 & -1 & -3 & -10 & -15 & - & - & - & - & +7 & +5 & -2 & -8 \\
\hline$\underline{\mathrm{Ph} / 100 \mathrm{bp} / 90}$ & +8 & +16 & +44 & +66 & +8 & +15 & +44 & +67 & +6 & +14 & +34 & +48 & +13 & +11 & +37 & +58 \\
\hline $\mathrm{Ph} / 100 \mathrm{bp} / 60$ & +4 & +8 & +23 & +35 & +4 & +8 & +23 & +36 & +3 & +7 & +18 & +26 & +10 & +3 & +16 & +28 \\
\hline $\mathrm{Ph} / 100 \mathrm{bp} / 40$ & +1 & +3 & +8 & +13 & +1 & +3 & +8 & +13 & +1 & +2 & +6 & +10 & +8 & -2 & +3 & +7 \\
\hline $\mathrm{Ph} / 100 \mathrm{bp} / 20$ & -1 & -2 & -6 & -9 & -1 & -2 & -6 & -9 & -1 & -2 & -5 & -7 & +5 & -7 & -11 & -13 \\
\hline $\begin{array}{c}\mathrm{Ph} / 100 \mathrm{bp} / 60- \\
40-20 * \\
\end{array}$ & +2 & +2 & -2 & -5 & +2 & +2 & -3 & -6 & +2 & +1 & -2 & -5 & +8 & -2 & -7 & -10 \\
\hline$\underline{\mathrm{Ph} / 180 \mathrm{bp} / 90}$ & +3 & +6 & +16 & +26 & +3 & +6 & +18 & +28 & +2 & +5 & +14 & +20 & +9 & +1 & +11 & +20 \\
\hline $\mathrm{Ph} / 180 \mathrm{bp} / 60$ & +1 & +1 & +4 & +7 & +1 & +2 & +5 & +8 & +1 & +1 & +4 & +6 & +6 & -3 & -1 & +2 \\
\hline $\mathrm{Ph} / 180 \mathrm{bp} / 40$ & -1 & -2 & -3 & -5 & -1 & -1 & -3 & -4 & -1 & -1 & -3 & -4 & +5 & -7 & -8 & -10 \\
\hline $\mathrm{Ph} / 180 \mathrm{bp} / 20$ & -2 & -5 & -12 & -17 & -2 & -5 & -12 & -18 & -2 & -4 & -10 & -14 & +3 & -10 & -17 & -21 \\
\hline $\begin{array}{c}\mathrm{Ph} / 180 \mathrm{bp} / 60- \\
40-20 *\end{array}$ & -1 & -3 & -11 & -16 & -1 & -2 & -11 & -16 & -1 & -3 & -9 & -13 & +5 & -7 & -15 & -20 \\
\hline
\end{tabular}

$42 \quad$ Underlined: reference scenarios

$43 \quad *$ : degressive cadmium concentration scenarios modelled over a 99-year period 
Table 3. Cd inputs related to applications of organic fertilizers tested in the model

\begin{tabular}{|c|c|c|c|c|}
\hline Fertilization scenario & $\begin{array}{l}\text { Mean Cd concentration in } \\
\text { fertilizing matter } \\
\left(\mathrm{mg} \cdot \mathrm{kg}^{-1} \mathrm{DM}^{*}\right)\end{array}$ & $\begin{array}{l}\text { Total amount of } \\
\text { nitrogen } \\
\left(\mathrm{kg} \cdot \mathrm{t}^{-1} \mathrm{DM}^{*}\right)\end{array}$ & $\begin{array}{l}\text { Amount of fertilizing } \\
\text { matter applied at the } \\
\text { Nitrate Directive } \\
\text { threshold of } 170 \\
\text { kg N.ha-1 } \\
\left(\mathrm{t} \mathrm{DM}^{*} \cdot \mathrm{ha}^{-1} \cdot \mathrm{year}^{-1}\right)\end{array}$ & 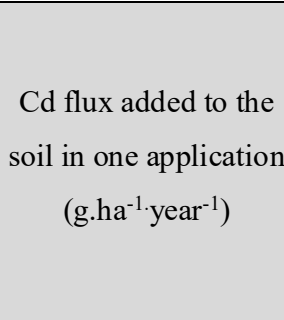 \\
\hline Sewage sludges (S) & 1.60 & Not applicable & $3 * *$ & 4.80 \\
\hline Cattle manure (CM) & 0.30 & 20 & 8.50 & 2.55 \\
\hline Farm anaerobic digestate (FAD) & 0.70 & 68 & 2.50 & 1.75 \\
\hline \multirow[t]{2}{*}{$\begin{array}{c}\text { Max Cd farm anaerobic } \\
\text { digestate (MaxCdFAD) *** }\end{array}$} & $\begin{array}{l}\text { Regulatory } \mathrm{Cd} \text { threshold } \\
\text { in digestate }\end{array}$ & $\begin{array}{c}\text { Total amount of } \\
\text { nitrogen } \\
\left(\mathrm{kg} \cdot \mathrm{t}^{-1} \mathrm{DM}\right)\end{array}$ & $\begin{array}{l}\text { Amount of fertilizing } \\
\text { material applied at the } \\
\text { threshold of } 170 \\
\quad \mathrm{kgN}^{-h^{-1}} \\
\left(\mathrm{t} \mathrm{DM} \cdot \mathrm{ha}^{-1} \cdot \mathrm{year}^{-1} \text { ) }\right.\end{array}$ & $\begin{array}{l}\text { Cd flux added to the } \\
\text { soil in one application } \\
\left(\text { g.ha }^{-1} \text { year }^{-1}\right)\end{array}$ \\
\hline & 3 & 68 & 2.50 & 7.50 \\
\hline
\end{tabular}

(From Plateau (2001), Brittany Chamber of Agriculture et al. (2007), IRSTEA and SOLAGRO (2012), Benoît et al. (2014), Wolf Environnement (2001))

** For sewage sludge, the maximum threshold authorised by the regulations was used, because the amounts of nitrogen and the physical nature of the sludge (liquid, paste or solid) can vary. We started from the maximum application threshold authorised by the regulations $\left(3 \mathrm{t} \mathrm{DM}^{\mathrm{D}} \mathrm{ha}^{-1}\right.$.year $\left.{ }^{-1}\right)$.

*** The proposed calculations include the Cd concentration proposed in the market authorisation specifications and the use of agricultural biogas 


\author{
Géraldine CARNE \\ Risk Assessment Department, \\ French Agency for Food, Environmental and Occupational Health \& Safety, \\ 14 rue Pierre et Marie Curie, 94701 Maisons-Alfort Cedex \\ FRANCE
}

Title of the manuscript: " Mass balance approach to assess the impact of cadmium decrease in mineral phosphate fertilizers on health risk: the case-study of French agricultural soils".

Authors: G. Carne, S. Leconte, V. Sirot, N. Breysse, P-M Badot, A. Bispo, I.Z Deportes, C. Dumat, G.

Rivière, A. Crépet

List of figures :

- Figure 1. Graphical abstract

- Figure 2. Schematic of the strategy for modelling cadmium exposure and risk using a massbalance approach integrating environmental sources of cadmium and fertilization scenarios

- Figure 3.Variation in Cd concentrations in matrices (soil, wheat grain, leachate) (expressed as percentages) at 10, 20, 60 and 99 years compared with the first year of application, based on mean and percentiles (P05, P25, P50, P75, P95) of Cd concentration in matrices, according to the wheat monoculture fertilization plan of $80 \mathrm{~kg} \mathrm{P}_{2} \mathrm{O}_{5} \cdot \mathrm{ha}^{-1} \mathrm{year}^{-1}$ simulating a constant $\mathrm{Cd}$ content of $90,60,40$ and $20 \mathrm{mg} \mathrm{Cd} \cdot \mathrm{kg} \mathrm{P}_{2} \mathrm{O}_{5}{ }^{-1}$ in the phosphate fertilizer (Ph/80b/90, Ph/80b/60, Ph/80b/40 and $\mathrm{Ph} / 80 \mathrm{~b} / 20$ fertilization plans) over a 99-year period

- Figure 4. Variation in $\mathrm{Cd}$ concentration in matrices (soil, wheat grain and potatoes, leachate) (expressed as percentages) after 10, 20,60 and 99 years compared with the first year of application, based on the means and percentiles (P05, P25, P50, P75, P95) of Cd concentration in matrices, according to the potato/wheat/wheat rotation fertilization plan of $180 \mathrm{~kg} \mathrm{P}_{2} \mathrm{O}_{5}$. ha${ }^{1}$.year ${ }^{-1}$ with a two year hiatus in fertilization, simulating a constant fertilizer $\mathrm{Cd}$ content of 90 , 60, 40 and $20 \mathrm{mg} \mathrm{Cd}$. kg $\mathrm{P}_{2} \mathrm{O}_{5}{ }^{-1}$ over a 99 -year period (Ph/180bp/90, Ph/180bp/60, Ph/180bp/40, $\mathrm{Ph} / 180 \mathrm{bp} / 20$ fertilization plans)

- Figure 5. Variation in Cd concentration in matrices (soil, wheat grain and potatoes, leachate) (expressed as percentages) after 10,20,60, 99 years compared with the first year of application, based on the mean and percentiles (P05, P25, P50, P75, P95) of Cd concentration in matrices, according to the potato/wheat/wheat rotation phosphate fertilization plan with $180 \mathrm{~kg} \mathrm{P}_{2} \mathrm{O}_{5}$. ha${ }^{1}$.year ${ }^{-1}$ including a two year hiatus in fertilization and using degressive fertilizer $\mathrm{Cd}$ concentrations over a 99-year period ( $\mathrm{Ph} / 180 \mathrm{bp} / 60-40-20)$

Figure 6. Percent variation (\%) in Cd concentration in French agricultural soils, according to their $\mathrm{pH}$ (acid, neutral or alkaline) and the $\mathrm{Cd}$ concentration of mineral phosphate fertilizers $(90,60$, 40 and $20 \mathrm{mg} \mathrm{Cd} . \mathrm{kg}_{2} \mathrm{O}_{5}{ }^{-1}$ ) between the first year of application and after 99 years for a wheat monoculture fertilization plan at $80 \mathrm{~kg} \mathrm{P}_{2} \mathrm{O}_{5}$. ha ${ }^{-1}$. year $^{-1}$ 
- Figure 7. Percentage of cases exceeding the health-based guidance value (HBGV) of $0.35 \mu \mathrm{g}$ Cd. kg bw ${ }^{-1} \cdot \mathrm{d}^{-1}$ and $95 \%$ confidence interval $\left(\mathrm{Cl}_{95 \%}\right)$ in the different scenarios, for French adults (a ) and children (b), under the upper bound (UB) hypothesis

- Figure 8. Variations (\%) in the mean and 90 percentile (P90) Cd contents in French agricultural soils, wheat grain and leachate matrices over a 99 -year period $(10,20,60,99$ years) compared with the first year of application and according to application of fertilizing materials based on a wheat monoculture plan 
FIGURES.

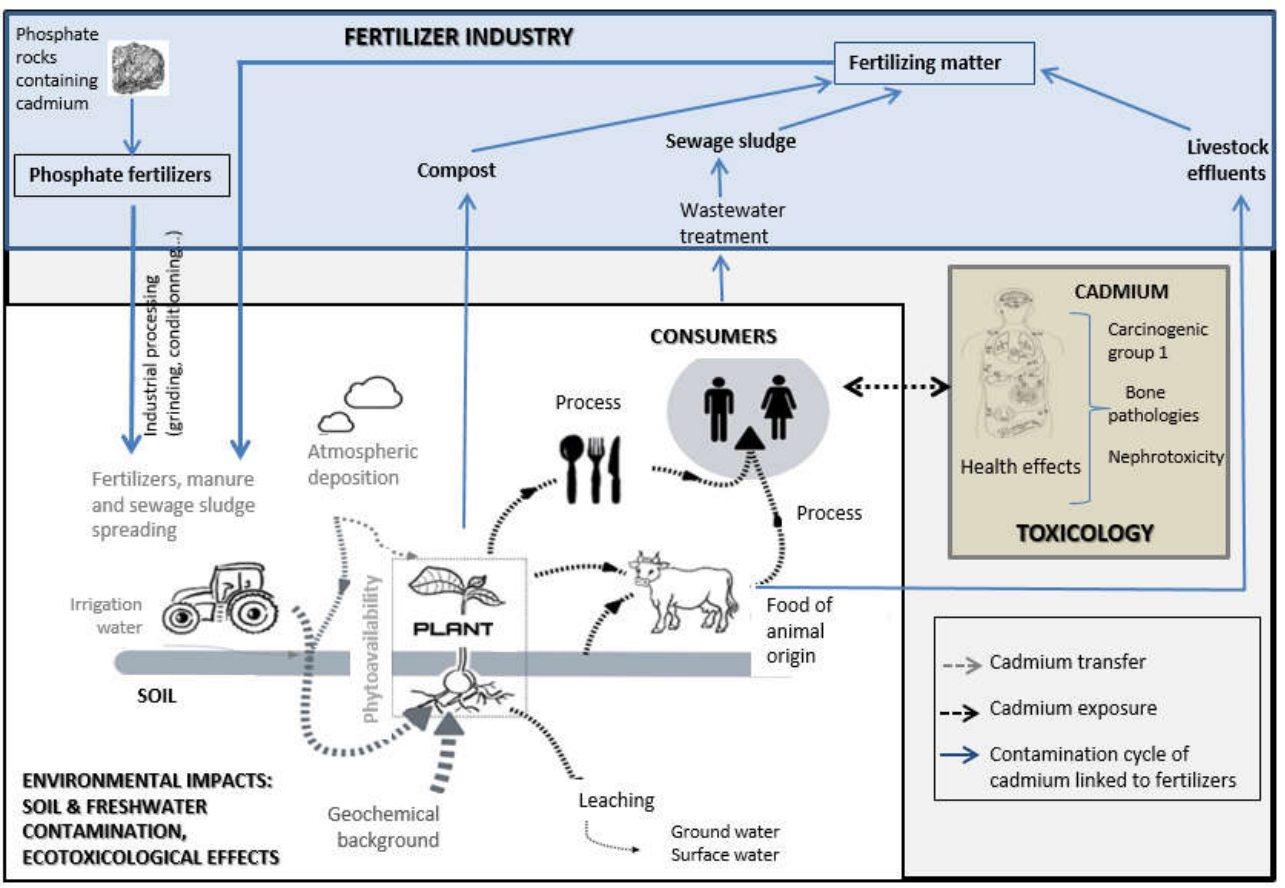

52

Figure 1. Graphical Abstract 


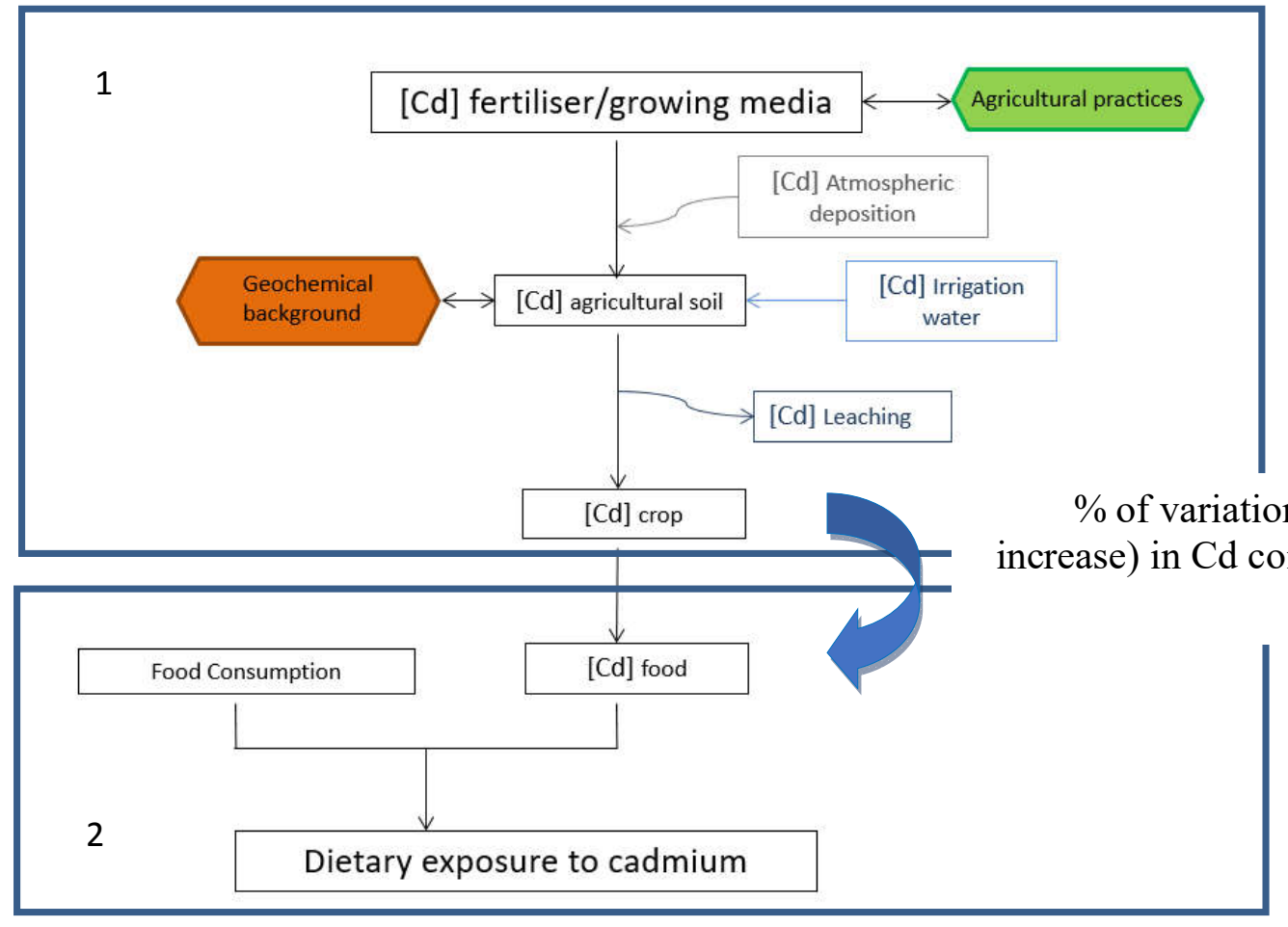

1. Mass-balance approach to model

Cd transfer from environmental sources to plants

Figure 2. Schematic of the strategy for modelling cadmium exposure and risk using a mass-balance approach integrating environmental sources of cadmium and fertilization scenarios 

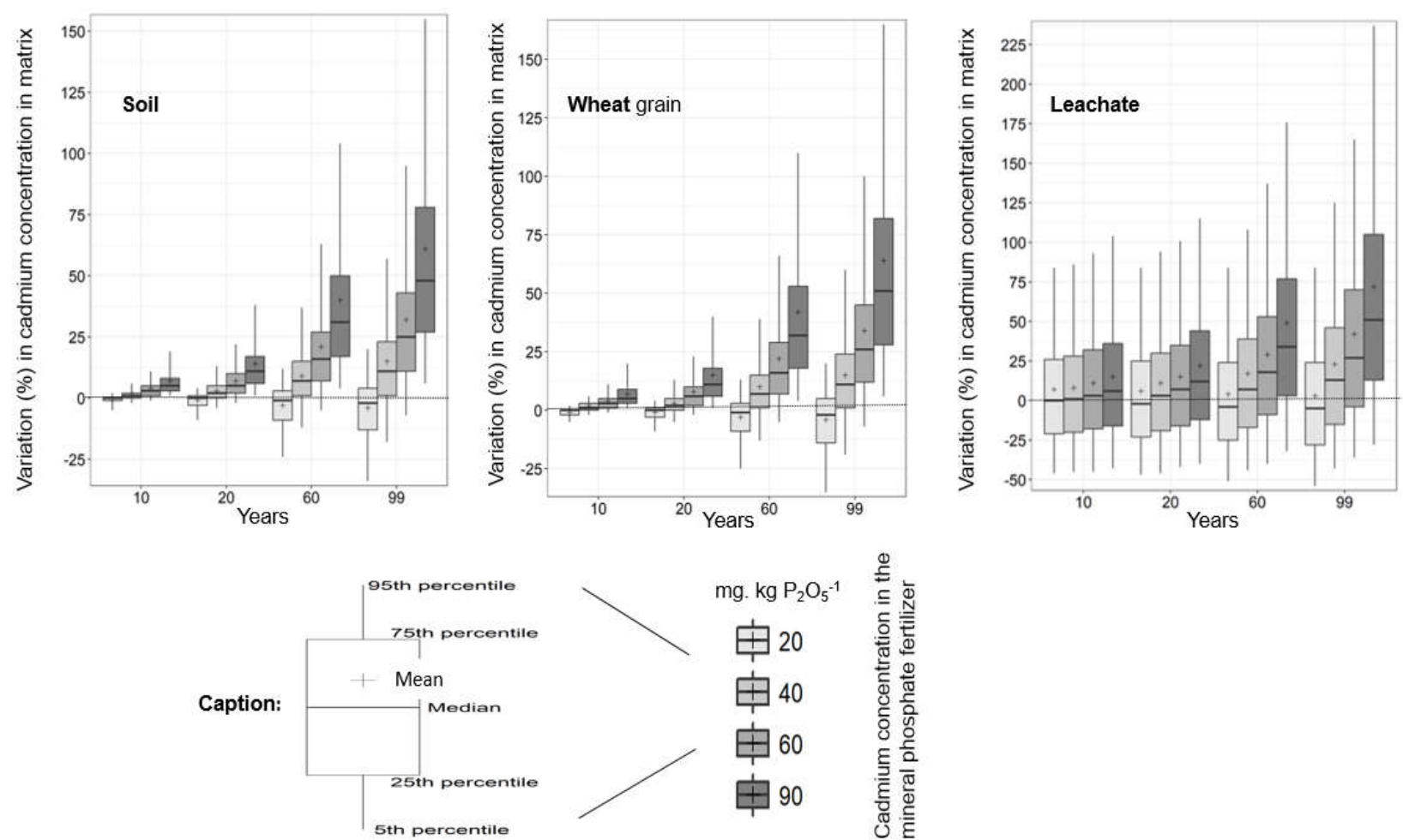

Figure 3. Variation in $\mathrm{Cd}$ concentrations in matrices (soil, wheat grain, leachate) (expressed as percentages) at 10, 20, 60 and 99 years compared with the first year of application, based on mean and percentiles (P05, P25, P50, P75, P95) of Cd concentration in matrices, according to the wheat monoculture fertilization plan of $80 \mathrm{~kg} \mathrm{P}_{2} \mathrm{O}_{5} \cdot \mathrm{ha}^{-1}$ year $^{-1}$ simulating a constant $\mathrm{Cd}$ content of $90,60,40$ and $20 \mathrm{mg}$ Cd.kg $\mathrm{P}_{2} \mathrm{O}_{5}{ }^{-1}$ in the phosphate fertilizer ( $\mathrm{Ph} / 80 \mathrm{~b} / 90, \mathrm{Ph} / 80 \mathrm{~b} / 60, \mathrm{Ph} / 80 \mathrm{~b} / 40$ and $\mathrm{Ph} / 80 \mathrm{~b} / 20$ fertilization plans) over a 99-year period 

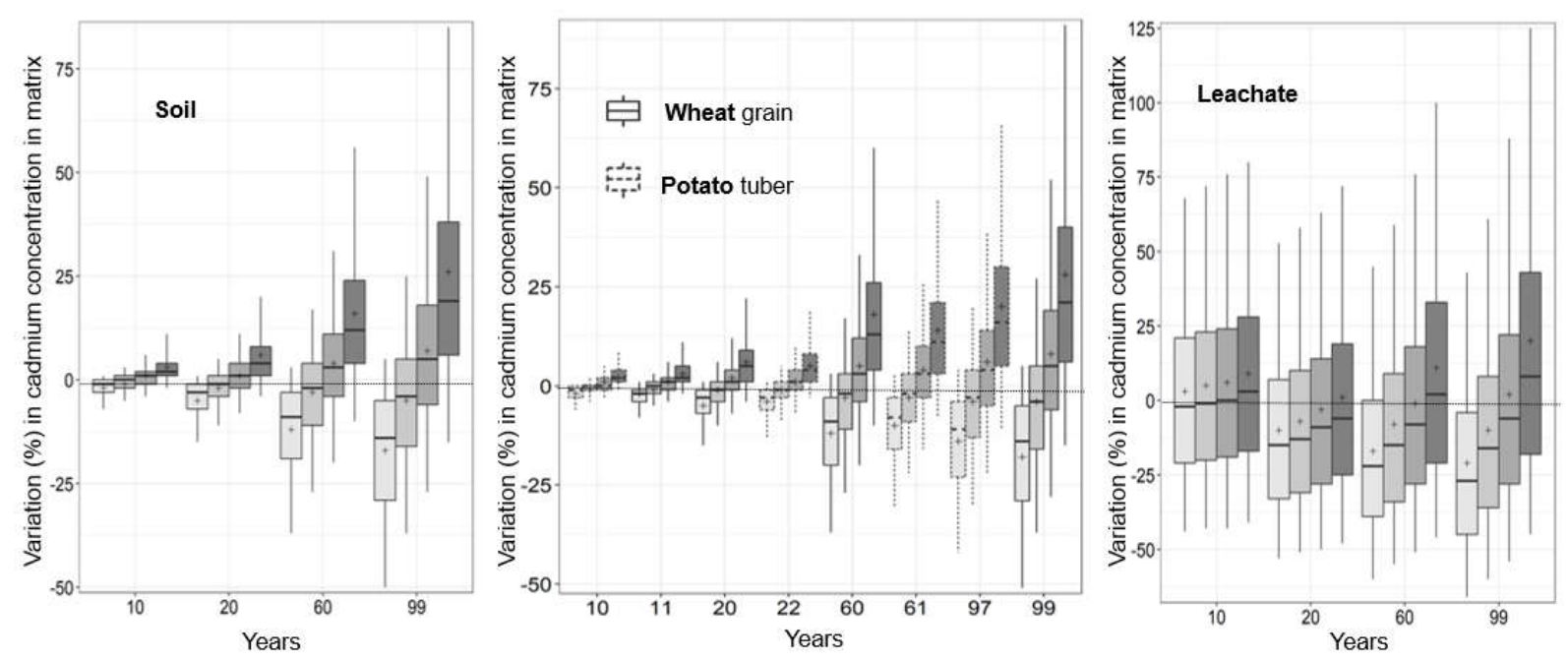

95

Figure 4. Variation in Cd concentration in matrices (soil, wheat grain and potatoes, leachate) (expressed as percentages) after 10, 20, 60 and 99 years compared with the first year of application, based on the means and percentiles (P05, P25, P50, P75, P95) of Cd concentration in matrices, according to the potato/wheat/wheat rotation fertilization plan of $180 \mathrm{~kg} \mathrm{P}_{2} \mathrm{O}_{5}$.ha-1.'year ${ }^{-1}$ with a two year hiatus in fertilization, simulating a constant fertilizer $\mathrm{Cd}$ content of $90,60,40$ and $20 \mathrm{mg} \mathrm{Cd}$. $\mathrm{kg} \mathrm{P}_{2} \mathrm{O}_{5}^{-1}$ over a 99year period ( $\mathrm{Ph} / 180 \mathrm{bp} / 90, \mathrm{Ph} / 180 \mathrm{bp} / 60, \mathrm{Ph} / 180 \mathrm{bp} / 40, \mathrm{Ph} / 180 \mathrm{bp} / 20$ fertilization plans)

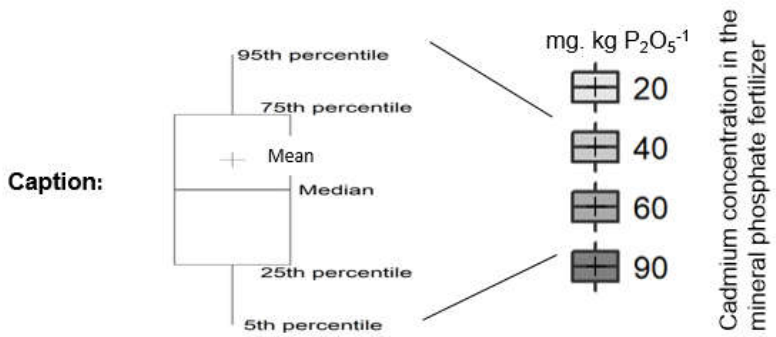




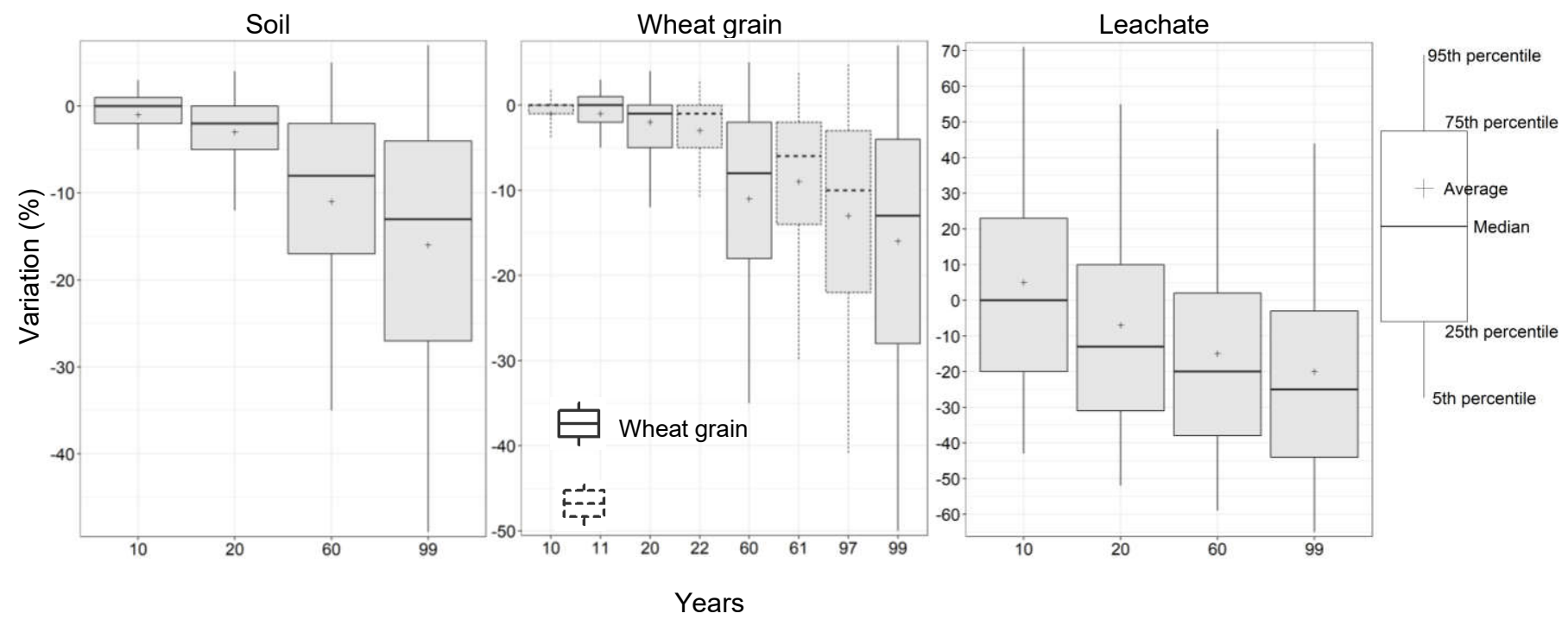

110

111

112

113

114

115

116

117

118

119

120

121

122

123

124

125

126

127

128

129

130

Figure 5. Variation in Cd concentration in matrices (soil, wheat grain and potatoes, leachate) (expressed as percentages) after 10, 20, 60, 99 years compared with the first year of application, based on the mean and percentiles (P05, P25, P50, P75, P95) of Cd concentration in matrices, according to the potato/wheat/wheat rotation phosphate fertilization plan with $180 \mathrm{~kg} \mathrm{P}_{2} \mathrm{O}_{5} \cdot$ ha $^{-1}$.year ${ }^{-1}$ including a two year hiatus in fertilization and using degressive fertilizer $\mathrm{Cd}$ concentrations over a 99-year period (Ph/180bp/60-40-20)

.




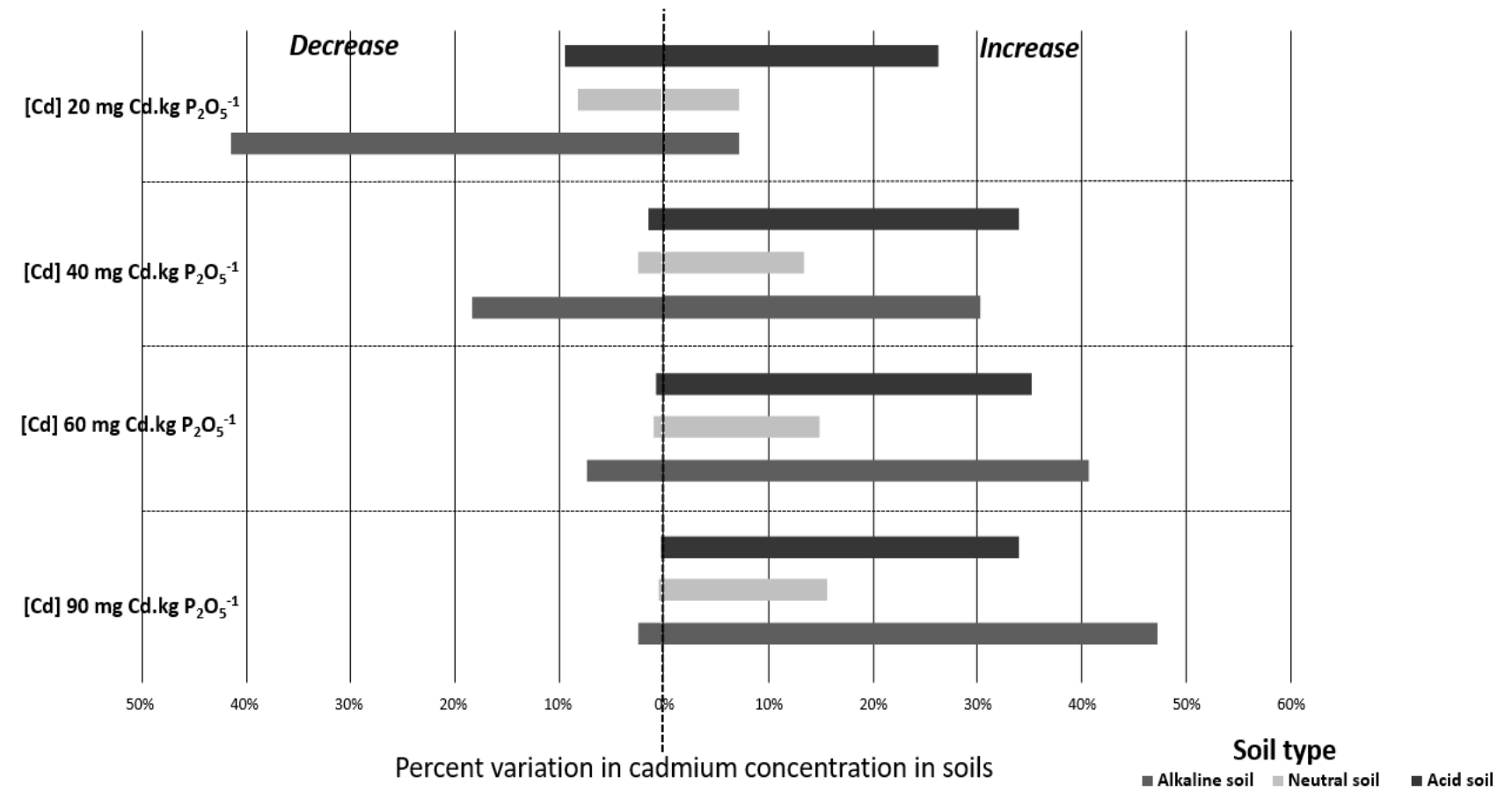

Figure 6. Variation (\%) of cadmium concentration in French agricultural soils, as a function of their $\mathrm{pH}$ (acid, neutral or alkaline) and the cadmium concentration of mineral phosphate fertilizers spread (90, 60, 40 and $20 \mathrm{mg} \mathrm{Cd} \cdot \mathrm{kg}_{2} \mathrm{O}_{5}^{-1}$ ) between the $1^{\text {st }}$ year of application and the 99-year period for a 


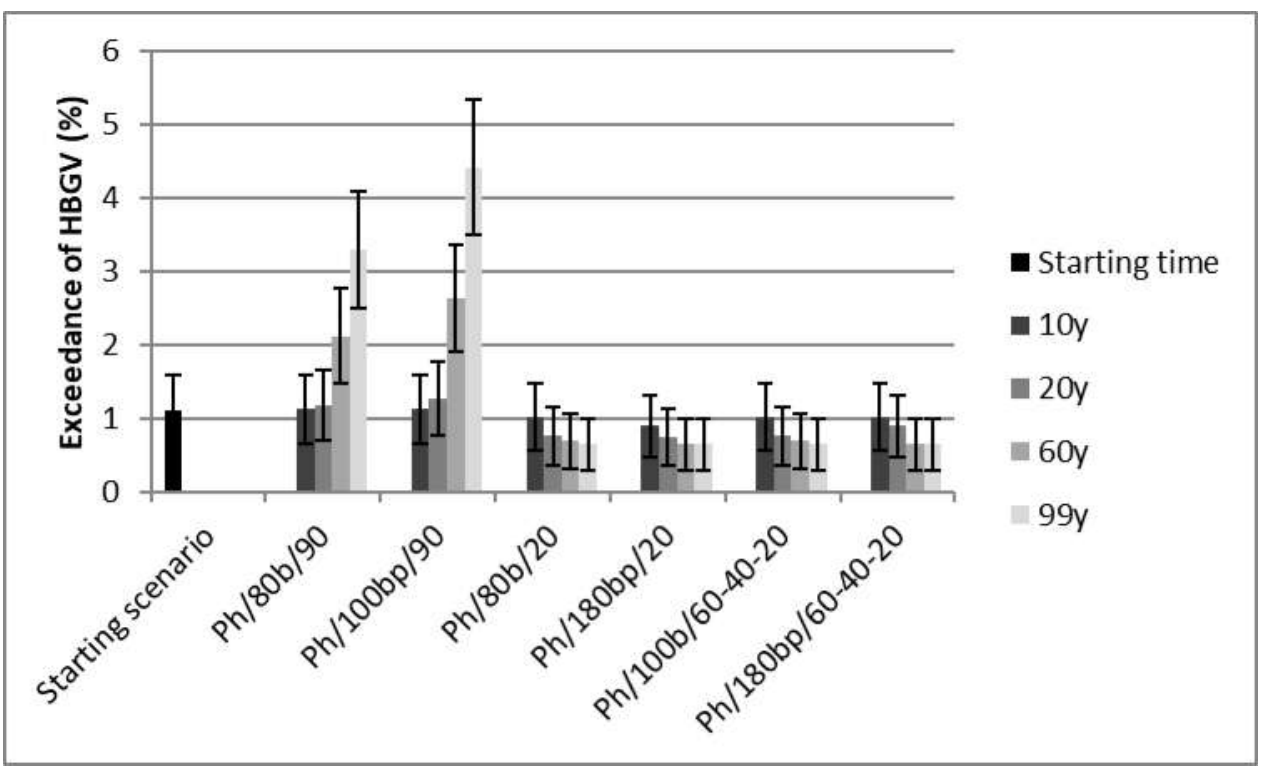

a)

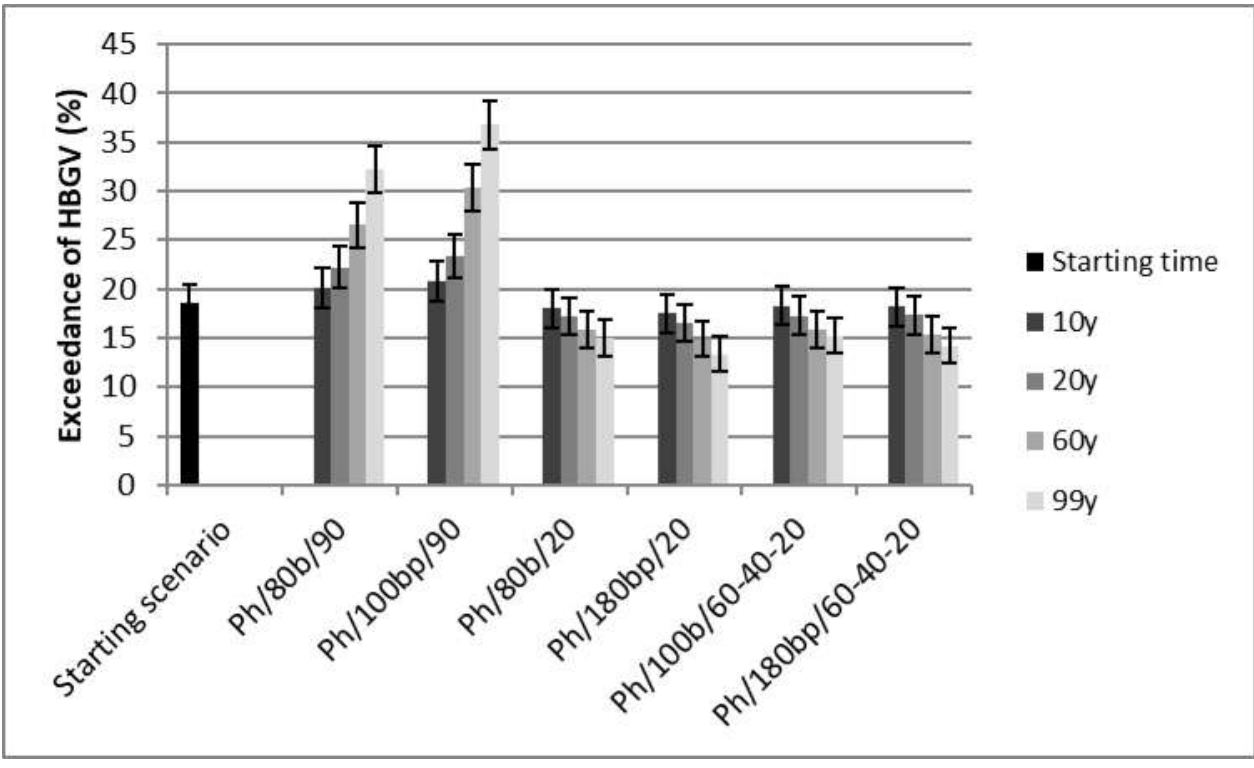

b)

Figure 7. Percentage of cases exceeding the health-based guidance value (HBGV) of $0.35 \mu \mathrm{g}$ Cd.kg bw ${ }^{1} . \mathrm{d}^{-1}$ and $95 \%$ confidence interval $\left(\mathrm{Cl}_{95 \%}\right)$ in the different scenarios, for French adults (a ) and children (b), under the upper bound (UB) hypothesis 


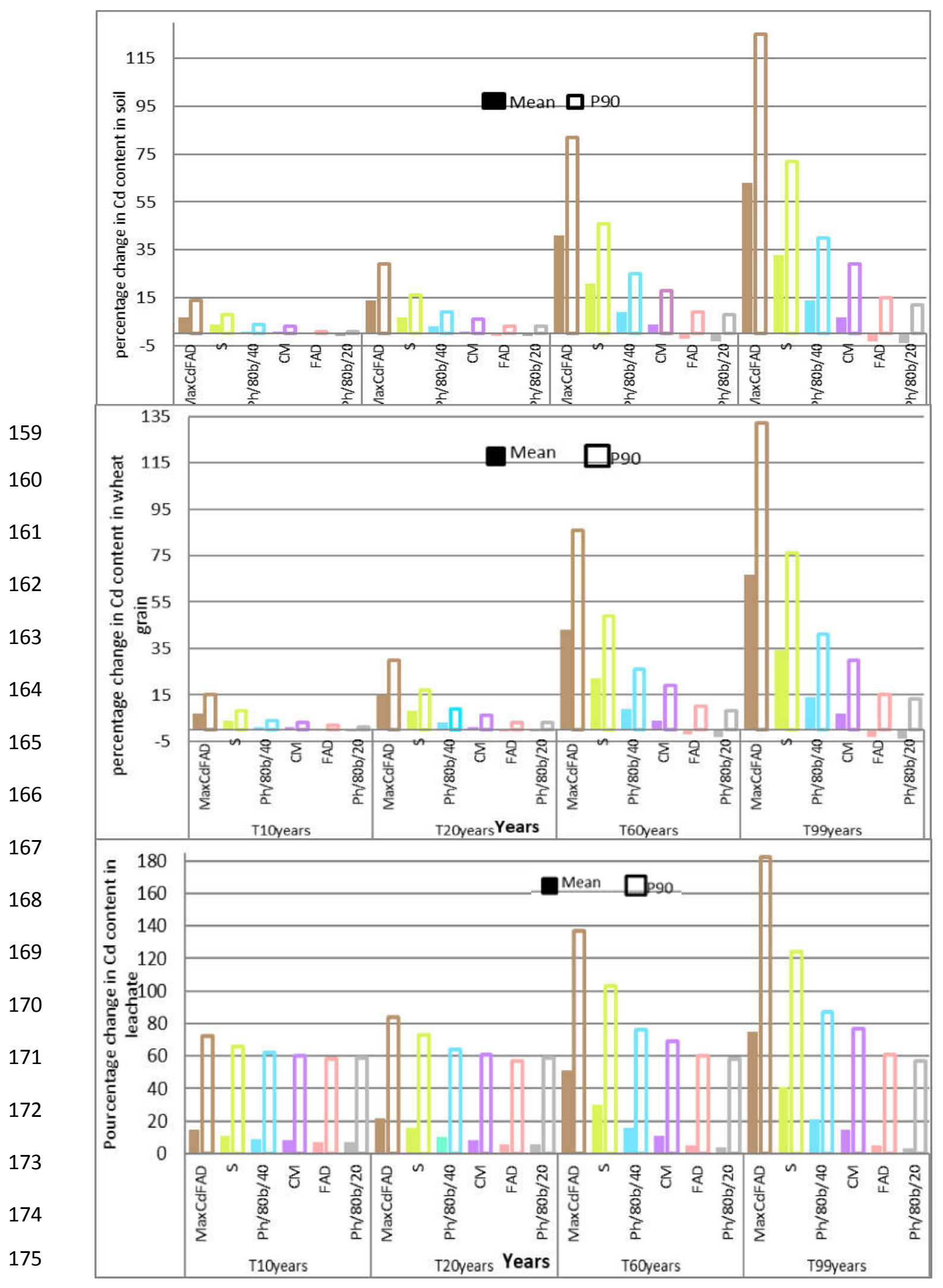


177 Figure 8. Variations (\%) in the mean and 90 percentile (P90) Cd contents in French agricultural soils, 178 wheat grain and leachate matrices over a 99-year period $(10,20,60,99$ years) compared with the first 179 year of application and according to application of fertilizing materials based on a wheat monoculture plan 